\title{
Environment for Development
}

Discussion Paper Series

Interaction between Crop Insurance and Technology Adoption Decisions

The Case of Wheat Farmers in Chile

César Salazar, Mónica M. Jaime, Cristián Pinto, and Andrés Acuña
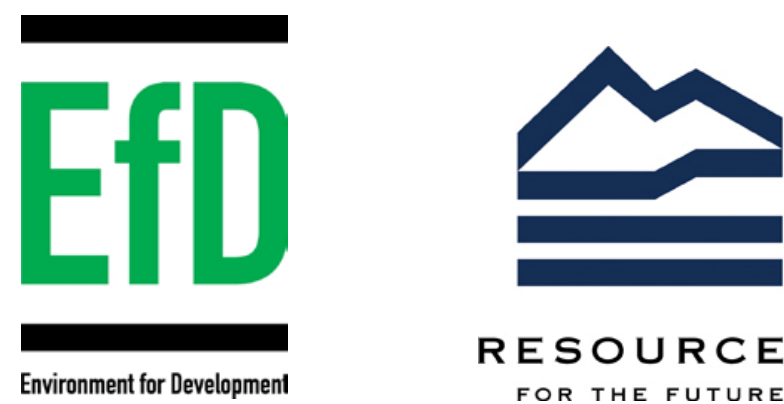

RESOURCES FOR THE FUTURE 


\section{Environment for Development Centers}

Central America

Research Program in Economics and Environment for Development in Central America Tropical Agricultural Research and Higher Education Center (CATIE)

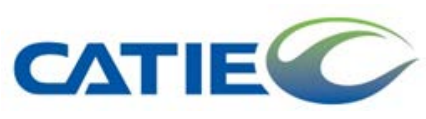

Colombia

The Research Group on Environmental, Natural Resource and Applied Economics Studies (REES-CEDE), Universidad de los Andes, Colombia<smiles>C1C2CC3CC1C3C2</smiles>
Universidad delosAndes

Kenya School of Economics University of Nairobi

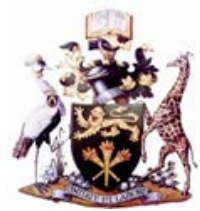

Tanzania

Environment for Development Tanzania University of Dar es Salaam

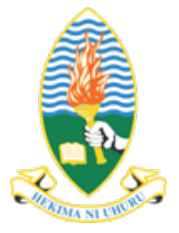

Chile

Research Nucleus on Environmental and Natural Resource Economics (NENRE)

Universidad de Concepción

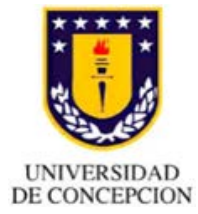

Ethiopia

Environment and Climate Research Center (ECRC)

Ethiopian Development Research Institute (EDRI)

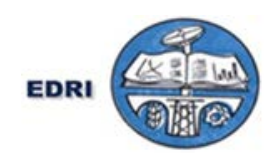

South Africa

Environmental Economics Policy Research Unit (EPRU)

University of Cape Town

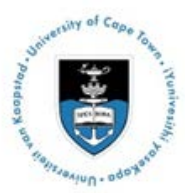

USA (Washington, DC)

Resources for the Future (RFF)

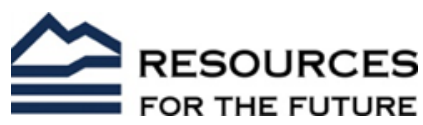

China

Environmental Economics Program in China (EEPC)

Peking University

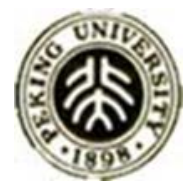

India

Centre for Research on the Economics of Climate, Food, Energy, and Environment, (CECFEE), at Indian Statistical Institute, New Delhi, India

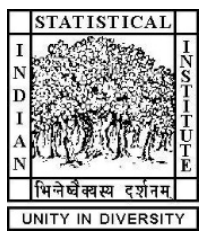

Sweden

Environmental Economics Unit University of Gothenburg
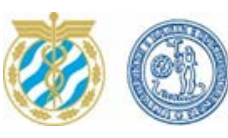

School of Business, Economics and Law UNIVERSTYY OF GOTHENBURG

\begin{abstract}
Vietnam
University of Economics Ho Chi Minh City, Vietnam
\end{abstract}

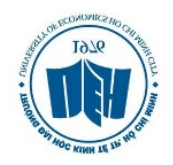

The Environment for Development (EfD) initiative is an environmental economics program focused on international research collaboration, policy advice, and academic training. Financial support is provided by the Swedish International Development Cooperation Agency (Sida). Learn more at www.efdinitiative.org or contact info@efdinitiative.org. 


\title{
Interaction between Crop Insurance and Technology Adoption Decisions: The Case of Wheat Farmers in Chile
}

\author{
César Salazar, Mónica M. Jaime, Cristián F. Pinto, and Andrés A. Acuña
}

\begin{abstract}
This paper examines relationships between crop insurance participation and input technology decisions among Chilean wheat farmers. Using nation-wide farm-level data from the National Agriculture and Forestry Census (INE 2007) a bivariate probit model is estimated. In this regard, we investigate the extent to which the adoption of certain production input technologies is associated with the participation of farmers in the state-promoted agriculture climate risk insurance program. We find that relationships between insurance and technology decisions are significant among family farmers, but this is not the case for large-scale farmers. Evidence also suggests that modern irrigation reduces the likelihood of adopting crop insurance, suggesting that Chilean farmers perceive these two options as substitutes. The latter implies that those using traditional irrigation methods preferentially participate in the insurance program, which can be taken as evidence of adverse selection in the Chilean insurance market.
\end{abstract}

Key Words: insurance adoption, farming technologies, adverse selection, bivariate probit model

JEL Codes: D81, D82, G22, Q12, Q14 


\section{Contents}

1. Introduction ..................................................................................................................................... 1

2. The Agricultural Sector and Crop Insurance in Chile............................................................ 3

2.1. The Agricultural Sector.............................................................................................. 3

2.2. Crop Insurance in Chile .................................................................................... 4

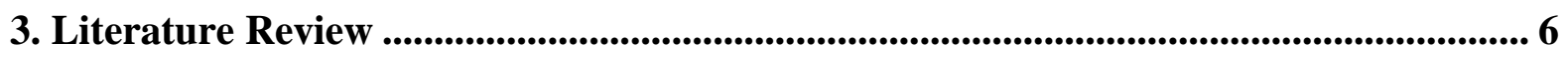

3.1. Crop Insurance Participation........................................................................................ 6

3.2. Crop Insurance and Production Input Technology ....................................................... 7

4. Theoretical Framework.................................................................................................................... 8

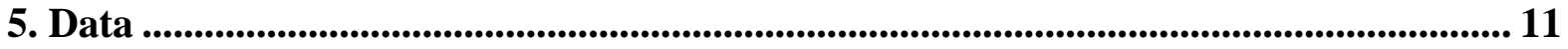

6. Empirical Strategy .................................................................................................................. 14

6.1. Adoption of Agricultural Insurance When Technology Decisions Are Exogenous.. 14

6.2. Adoption of Agricultural Insurance and Technology When Farmers' Decisions Are Jointly Made............................................................................................................. 15

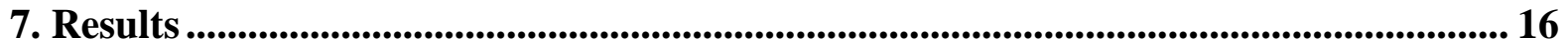

7.1. Adoption of Agricultural Insurance ....................................................................... 16

7.2. Technology Adoption and Agricultural Insurance ……............................................... 19

8. Robustness Checks.................................................................................................................... 20

8.1. Adoption Decisions in Homogeneous Areas ........................................................... 20

8.2. Assessing Technological Change among Irrigators.................................................... 20

8.3. Controlling for Multiple Relationships ...................................................................... 20

8.4. Instrumental Variable Approach.................................................................................... 21

9. Conclusions............................................................................................................................. 21

References............................................................................................................................................ 24

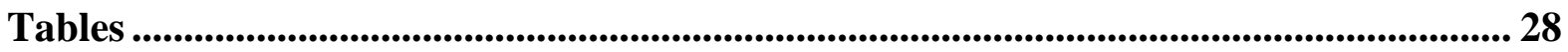

Appendix A. Additional Tables and Figures ................................................................................. 34 


\title{
Interaction between Crop Insurance and Technology Adoption Decisions: The Case of Wheat Farmers in Chile
}

\author{
César Salazar, Mónica M. Jaime, Cristián F. Pinto, and Andrés A. Acuña*
}

\section{Introduction}

Agricultural production is frequently exposed to a variety of perils. Zorrilla (2002) identifies five categories of agricultural risks: climatic (e.g., hail, frost, drought, flood, wind, fire, snow, etc.), sanitary (e.g., plagues and diseases), geological (e.g., earthquakes and volcanic eruptions), market (e.g., domestic and international price volatility and changes in quality standards, preferences, etc.), and man-made risks (e.g., institutional reforms, wars, economic and social crises, etc.). In theory, there is a wide array of informal risk management strategies that farmers can use in order to mitigate agricultural risks. These strategies include crop diversification, savings accumulation, off-farm activities, and adoption of risk-reducing production technology (Dercon 2002). In contrast, there are more sophisticated strategies that deal with risks in a systemic way by developing a risk market approach. Among these formal strategies are forward contracts, futures and options commodity markets, revenue insurance and crop insurance (Dercon 2002). The latter strategies are not always available for small-scale farmers in developing countries and, in some cases, markets are incomplete or do not work properly.

In Latin America, climate events are the most important risk for farming production. In that regard, governments have designed and promoted different policies in order to reduce farmers' vulnerability. Multi-peril crop insurance and state-funded disaster relief programs are the main public policy responses regarding risk management in agriculture (Vila et al. 2011). ${ }^{1}$ The experience with crop insurance instruments in Latin

\footnotetext{
* César Salazar, Corresponding Author, email: csalazar@ubiobio.cl, Department of Economics and Finance, and Applied Sectorial Economics Research Group (GI 160317/EF), Universidad del Bio-Bio. Mónica M. Jaime, School of Management and Business, Research Nucleus on Environmental and Natural Resource Economics (NENRE), University of Concepción. Cristián Pinto and Andres Acuña, Department of Economics and Finance, and Applied Sectorial Economics Research Group (GI 160317/EF), Universidad del Bio-Bio.

1 These risk management policies are implemented in different modalities across the region. According to Vila et al. (2011), in Brazil, Colombia, Chile, Ecuador, Mexico, Perú and Uruguay, the public sector supports the private insurance industry by providing subsidies for crop insurance and other instruments of risk management, as well as management assistance and state guarantees, while in Bolivia the state runs a universal coverage agricultural insurance program. In contrast, Argentina has chosen to develop a private crop insurance industry and to ease access to derivative markets for the most important agricultural products.
} 
American countries is generally similar. A low level of participation, especially among small farmers, is the most significant feature (Wenner 2005). In the case of Chile, the crop insurance participation rate has been rather low, reaching only $10 \%$ of the total arable farming area in the coverage area in 2012 (COMSA 2012).

There are several potential explanations for this phenomenon. From a general perspective, many studies have attempted to explain it by focusing on asymmetric information problems that relate to adverse selection and moral hazard issues (see, e.g., Gardner and Kramer 1986; Quiggin et al. 1993; Coble et al. 1996; Makki and Somwaru 2001). In the case of developing countries, information asymmetries are exacerbated by budgetary restrictions among market participants and high administrative costs of providing sound actuarial studies, promotion and supervision for individual insured farmers, as well as inadequate procedures for assessing indemnities (Hazell 1992).

In this paper, our aim is to address the problem of farmer participation in crop insurance by exploring the relationship between crop insurance adoption and production technology choices. Given that agricultural risks are diverse and the coping strategy can be multi-layered, some input decisions may have an influence on the degree to which a farm is exposed to risks (Horowitz and Lichtenberg 1993). In this case, the decision whether to adopt insurance can be influenced by input technology choices. We will focus our attention on the Chilean crop insurance market, specifically for the wheat farming sector, making a distinction between medium-large farms and small-scale farms. Available data come from the 2007 National Agriculture and Forestry Census. Given the nature of this information, we examine the farmer's probability of making a certain decision. In particular, we want to find out whether there is any relationship between the farmer's decision whether or not to buy insurance and her decision whether or not to adopt a specific technology. A problem of endogeneity may arise because these decisions might be affected jointly by an unknown underlying process (simultaneity) or they could affect each other in both directions (reverse causality). For instance, a farmer might decide to adopt or not adopt a certain technology because he is insured; similarly, he might buy insurance or not buy insurance because he uses a certain technology. Because it is difficult to find an appropriate and observable instrumental variable, we deal with estimation bias by setting up and estimating a bivariate probit model as a joint model for these two binary outcomes and then examining the correlation between them. If a significant correlation is found, the decisions are interrelated and the bivariate model will be more appropriate. 
Following Foudi and Erdlenbruch (2012), the relationship between insurance adoption and irrigation technology is explored; nevertheless, this paper differs from that study in a number of aspects. First, we focus on the farmer's decision to adopt insurance, rather than on farm production functions, so multiple explanations for insurance adoption are examined. Consequently, a different theoretical framework, data structure, and estimation methods are used. Second, the role of technology adoption is further analyzed by incorporating a broader set of input technologies, such as crop seed selection and biological control, and results between small and large-scale farmers are compared. Each technology is expected to interact with agricultural insurance in a different way, depending on its characteristics, as well as on the scale of the farming operation. For example, modern irrigation is expected to reduce vulnerability to water shortages in a manner similar to insurance, in that both function as risk-reducing strategies. The adoption of certified seed is expected to interact with climate risk, although somewhat weakly, while biological control is not expected to be directly related to climate risk. Finally, to our knowledge, this is the first study aimed at explaining farming insurance behavior and the interaction between agricultural technologies in the context of the Chilean agricultural sector.

The rest of the article is organized as follows. Section 2 describes the characteristics of the agricultural sector and crop insurance program in Chile. Section 3 discusses the related literature. Section 4 reviews a conceptual framework that links insurance and technology adoption decisions. Section 5 presents the data used and Section 6 the econometric model. Section 7 discusses the main results. Section 8 considers a number of robustness tests and Section 9 concludes.

\section{The Agricultural Sector and Crop Insurance in Chile}

\subsection{The Agricultural Sector}

The agricultural sector is at the core of the Chilean economy, and it is the basis of an important value chain that includes food manufacturing and tourism. This sector accounts for around 15\% of the country's GDP and employs $12 \%$ of the labor force; more than $50 \%$ of its production is sold in international markets, making the sector highly dependent on world market prices. Agriculture also contributes to the food security of the country, especially through small-scale agriculture, which plays an important role in the agricultural sector in Chile (FAO 2009). Family or small-scale agricultural producers provide around $60 \%$ of the food consumed in the domestic market and control $85 \%$ of 
total farms in the country, comprising 1.2 million people, and generating 60,000 direct and indirect jobs. These producers are mainly involved in traditional farming activities, hire family members, and operate at low levels of working capital (INDAP 2011).

Agriculture benefits from the vast climate diversity in Chile, which allows a wide range of cropping activities. Some major agricultural products include fruit (i.e., grapes, apples, pears, peaches and berries), horticulture (i.e., garlic, onions and asparagus), and cereal and tubers (i.e., wheat, maize, and potatoes). Wheat is the most relevant annual crop in the world, in general, and in Chile, in particular. This crop occupies around 50\% of the surface devoted to annual crops in Chile, confirming its economic and social importance for agricultural income-dependent farmers. Moreover, this crop extends across most of the territory and its distribution can be classified into distinct agro-climatic zones.

\subsection{Crop Insurance in Chile}

The Farm Insurance Program (hereinafter FIA) was created in 2000 by the Chilean Ministry of Agriculture. Its main goal is to protect farmers against economic loss resulting from the most frequent climate events, such as droughts, heavy or untimely rains, freezes, blizzards, and hail. The program subsidizes farmers who buy crop insurance. The insurance covers not only annual crops such as cereals, vegetables, industrial crops, legumes, grains and potatoes, but also fruit plantations. The insurance policy assures the farmer of up to two-thirds of the potential value of the crop.

The FIA is supervised by the Agricultural Insurance Committee (hereinafter COMSA), a government agency in which the Agriculture, Finance, and Economy ministries are represented. This agency is operated by private insurance companies, supported by an extensive network of government institutions, private agents and brokers. Subsidy payments are channeled through CORFO, a governmental business promotion agency, directly to the insurance companies according to the number of policies issued.

According to COMSA (2012), the premium cost subsidy consists of a fixed contribution of 1.5 Foment Units (UF by its Spanish acronym) (USD 50) for each policy, plus $50 \%$ of the net premium cost with an 80 UF (USD 3,000) cap payment per farmer (all values for one season). For small farmers, the subsidy may account for up to $80 \%$ of the premium cost. There are no major restrictions as to what type of farmers can be beneficiaries of the subsidy, beyond being registered at the Internal Tax Service (SII) or 
being a banking customer, or having been approved for credit by a government promotion agency. At the beginning of each season, the insurable areas and crops are established under the concept of Homogeneous Insurable Area (HIA). The coverage areas go from Coquimbo Region (Region IV) to Los Lagos Region (Region X), plus Copiapó (Region III), Vallenar (Region III), Lluta, Azapa (Region I), and Chaca valleys. These regions account for approximately $70 \%$ of the Chilean territory. The coverage starts from the sowing period or the date of the acceptance of risk by the insurer, and ends at the end of harvest or the date established by the contract.

The crop insurance policy covers two-thirds of the expected crop yield. Under some conditions for specific crops, coverage might reach three-fourths. For example, with a two-third coverage, if the expected yield is 30 units per hectare, and the farmer obtains 15 units per hectare due to some of the climate events specified in the policy, the insurance company will compensate the farmer for 5 units per hectare, at market price per unit. This price must be below a maximum price that is determined beforehand. Coverage percentage, standard yield range, maximum compensation prices, maximum and minimum premium rates, and other technical parameters of the insurance contract are specified for every crop, crop type, geographic area (known as insurance homogeneous zone), and sowing-harvest calendar, in a document known as "Subscription Norms," which is issued annually by COMSA before each farming season. Insurance coverage begins at the start of the sowing period, and ceases at the end of harvest of the entire crop.

Premiums are determined by applying a premium rate on the amount insured plus 0.6 UF. The amount insured is the coverage percentage (either two-third or three-fourth) multiplied by the standard yield (per hectare), multiplied by the total surface of the crop, multiplied by the estimated market unit price of the crop product. Maximum premium rates are specified in the Subscription Norms.

When a farmer decides to insure an annual crop, she has to apply for an insurance policy by presenting a "Crop Insurance Proposal” to the insurance company. This is an application form where the farmer must declare specific information regarding the location and dimension of the crop, type of soil, irrigation, type of seed, sowing density, use of agrochemicals, and estimated dates of sowing and harvest. The farmer must also declare the expected yield of the crop. The expected yield must fall within the range specified in the Subscription Norms. If an adverse climate event that is covered by the insurance policy occurs, the farmer must immediately notify the insurance company. The 
insurance company will designate a claim adjuster who, in turn, will name an inspector with the necessary expertise to verify and evaluate the damage to the crop. The farmer must notify the insurance company that an adverse weather event occurred before the start of harvest, in order to verify the real yield obtained from the crop. The insurance company, based on the incident reports and the real crop yield, will issue an insurance adjustment report establishing the amounts and date of any compensation payment.

By the year 2012, the program was financing over 20,600 policies annually, 75\% of which were taken out by small farmers as part of a loan contract with INDAP (National Institute for Agricultural Development), the main agricultural promotion agency. The total farming area covered by the insurance was approximately 105,000 hectares. At the same time, COMSA had identified 270,000 potential farmers who were eligible to participate in the program, which includes almost all farmers actively operating. Of that number, 150,000 farms made up the target group for insurance. The total arable farming area in the potential coverage area is estimated at 1,086,000 hectares (COMSA 2012).

\section{Literature Review}

\subsection{Crop Insurance Participation}

One of the first experiences of an insurance program was the Federal Crop Insurance Corporation, which was created in 1938 in the United States to help farmers recovering from the great drought known as the “dust bowl.” However, crop insurance was not a relevant field for academic discussion until the enactment of the Federal Insurance Act of 1980, which expanded the crop insurance program to more crops and regions in the U.S. by establishing a premium subsidy for the benefit of farmers. The first challenge the enhanced program faced was the lower than expected level of participation and the consequent economic losses of the program due to insufficient premium income. As highlighted by Hazell (1992), this public policy was demonstrated to be ineffective in practice, mainly because small growers could not afford an expensive insurance premium, although it was subsidized. Moreover, the incentives to moral hazard behavior and farmer-insurer collusion were not eradicated after its implementation. These issues motivated a series of studies aimed at explaining the elements that were driving crop insurance adoption decisions as well as detecting asymmetric information imperfections in the insurance market, in particular, the eventual presence of adverse selection. 
One of the first empirical studies on crop insurance participation decisions was conducted by Gardner and Kramer (1986). Using county-level data, the authors found that the expected rate of return on insurance has a positive and statistically significant effect on crop insurance participation. This result was also supported by subsequent similar studies (Hojjati and Bockstael 1988; Barnett et al. 1990) that suggest the presence of adverse selection as one of the reasons for the low participation rate observed in crop insurance markets. Quiggin et al. (1993) stressed the problem of distinguishing between adverse selection and moral hazard when explaining insuring behavior. They used crosssectional data for the 1988 crop year to estimate a corn farm production function. They found a negative and significant effect of insurance adoption and expected output and questioned the viability of a multi-peril crop insurance program in light of the contradicting incentives for farmers. Similarly, Coble et al. (1996), using cross-sectional data at the farm level, developed a formal crop insurance participation model, finding statistically significant effects on participation of both market return and return to insurance, as well as both market return and return to insurance variance. They also found participation to be inelastic to premiums. Just et al. (1999) examined adverse selection in U.S. crop insurance using nationwide data. They suggest that farmers who participate in the crop insurance program tend to have positive expected benefits from insurance participation, while uninsured farmers have negative expected benefits, reflecting deficiencies in pricing insurance for lower-risk farmers. In the same direction, Makki and Somwaru (2001) concluded that high-risk farmers are more likely to purchase revenue insurance and are undercharged with respect to lower-risk farmers for a comparable insurance contract. Sherrick et al. (2004) concluded that midwestern farmers who engage more extensively in insurance are the ones who operate larger acreages, are more highly leveraged, are less wealthy and have higher yield risks.

\subsection{Crop Insurance and Production Input Technology}

An interesting aspect in the crop insurance literature is that of input technology as a determinant of insurance adoption. On the one hand, risk-reducing inputs such as irrigation techniques could act as a substitute for insurance policies. Foudi and Erdlenbruch (2012) explored the role of irrigation technology in the farming production process, finding that irrigating farmers have larger average profits with less variance than non-irrigating farmers, and also that irrigating farmers are less likely to purchase yield insurance. On the other hand, the farmer's choice of the specific usage amount of some production inputs such as fertilizers and pesticides may increase the risk-return profile of 
the farm operation, making room for the appearance of moral hazard issues. Horowitz and Lichtenberg (1993) found evidence that insured farmers significantly use more fertilizers, herbicides and pesticides, suggesting the presence of moral hazard if these inputs are considered risk-increasing production technologies. However, Babcock and Hennessy (1996) found no support for the hypothesis that insurance increases optimal fertilizer application rates. They concluded that nitrogen fertilizer and insurance are substitutes, suggesting that those who purchase insurance are likely to decrease nitrogen fertilizer applications. Smith and Goodwin (1996) noticed that the insurance participation decision is more or less contemporaneous with input choices. Their conclusions indicated that crop insurance participation has a significant negative effect on total chemical input expenditures. Along the same lines, Goodwin et al. (2004) included the use of fertilizer in a model of participation in crop insurance for corn and soybean farmers, finding a statistically significant negative relationship between these two variables.

\section{Theoretical Framework}

Our theoretical approach adapts the insights and theory proposed by Giné and Yang (2009) and Mobarak and Rosenzweig (2012). Thus, the model that guides this empirical study is based on the following assumptions and relationships.

Suppose that a farmer has to make a decision about the implementation of a technical change, $T A$, which has three potential forms: hybrid seeds $(S)$, enhanced irrigation $(I)$, and biological control $(B)$. All of them involve a higher but riskier average yield. That is, if the farmer does not implement one of the above improvement alternatives, then the yield will be equal to $Y_{T}$. If the farmer introduces the improvement $T A$, then he could produce a higher yield $Y_{H}$ with probability $p$ or a lower yield $Y_{L}$ with probability (1-p). As pointed out by Mobarak and Rosenzweig (2012), assume that probability $p$ further captures whether the technical change is a risk-decreasing or riskincreasing technology. That is to say, if $p^{\prime}(T A)>0$ and $p$ '' $(T A)<0$, then the farmer's decision leans toward a risk-decreasing technology. Conversely, it holds that $p^{\prime}(T A)<0$ and $p^{\prime \prime}(T A)>0$ for a risk-increasing technology.

Moreover, the adoption of the technical change guarantees that:

$$
Y_{T}<p(T A) Y_{H}+(1-p(T A)) Y_{L}
$$


where the variable TA denotes the technical change adopted by the farmer. Therefore, $p(T A)$ is the probability for a higher yield $Y_{H}$ after adopting the technical change TA. The inequality stated in (1) holds for all the improvement alternatives and implicitly suggests that the farmer discriminates among them. Given that the competitive price of the crop is normalized to one and that technical change is costly, $C$, it is assumed that $C<Y_{L}$. Therefore, if a farmer draws a distinction among two technologies $i$ and $j$, then she strictly prefers technical change $i$ over the alternative $j$ if the following condition is true:

$$
p(i) Y_{H}+(1-p(i)) Y_{L}-C^{i}>p(j) Y_{H}+(1-p(j)) Y_{L}-C^{j} ; \text { for } i \neq j
$$

where $p(i)$ and $p(j)$ are the probabilities for a higher yield $Y_{H}$ related to technical improvement $i$ and $j$, respectively, while $C^{i}$ and $C^{j}$ represent the cost of implementing the above technologies, $C^{i} \neq C^{j}$. Thus, the farmer will select a technical change that provides a larger expected profit after deducting the cost of its implementation.

In order to address the insurance adoption decision, assume that farmers hold a set of illiquid assets, $W$, where $C<W$. Hence, under the uninsured scenario, the expected utility of a farmer who chooses the productive enhancement $i, \mathrm{U}_{\mathrm{u}}{ }^{\mathrm{i}}$, will be equal to:

$$
U_{u}^{i}=p(i) U\left(Y_{H}-C^{i}+W\right)+(1-p(i)) U\left(Y_{L}-C^{i}+W\right)
$$

where $U(\cdot)$ is a continuous and increasing utility function.

On the other hand, the financial system offers rainfall insurance that allows distributing risk costs over time and among producers. The insurance contract includes an indemnity equal to $R$, which covers the technology investment, $C$, and the potential loss from the casualty, $M$. The contract further assumes that $q$ is the probability of high rainfall $(h)$ and $(1-q)$ the probability of poor rainfall $(l)$.

Additionally, suppose that the insurer faces problems of adverse selection, which could be avoided by setting a premium that considers the characteristics and risk profile of the farmer. Formally, the insurance premium, $D$, depends on technological risk, $\gamma$, crop risk, $\phi$, and farmer's wealth, W. As remarked by Giné and Yang (2009), if the insurance premium $D$ is fairly priced, then it will be equal to $(1-q) R$. Thus, the expected utility of a farmer who decides to adopt a productive enhancement $i$ and take the rainfall insurance, $U_{I}^{i}$, will be equal to: 


$$
\text { (4) } \begin{aligned}
U_{I}^{i}= & f\left(Y_{H}, T A, h\right) U\left[Y_{H}-C^{i}-D(\gamma, \phi, W)+W\right]+f\left(Y_{H}, T A, l\right) U\left[Y_{H}-D(\gamma, \phi, W)+R+W\right] \\
& +f\left(Y_{L}, T A, h\right) U\left[Y_{L}-C^{i}-D(\gamma, \phi, W)+W\right]+f\left(Y_{L}, T A, l\right) U\left[Y_{L}-D(\gamma, \phi, W)+R+W\right]
\end{aligned}
$$

where $f(\cdot)$ is the joint probability density function for yield, technology, and rainfall. Therefore, when a farmer decides to buy weather insurance, technologies $i$ and $j$ are substitutes for insurance if the following condition holds:

$$
\begin{aligned}
& f\left(Y_{H}, i, h\right) U\left(Y_{H}, C^{i}, D^{i}, W\right)+f\left(Y_{H}, i, l\right) U\left(Y_{H}, D^{i}, R, W\right)+f\left(Y_{L}, i, h\right) U\left(Y_{L}, C^{i}, D^{i}, W\right) \\
(5)+ & f\left(Y_{L}, i, l\right) U\left(Y_{L}, D^{i}, R, W\right)=f\left(Y_{H}, j, h\right) U\left(Y_{H}, C^{j}, D^{j}, W\right)+f\left(Y_{H}, j, l\right) U\left(Y_{H}, D^{j}, R, W\right) \\
& +f\left(Y_{L}, j, h\right) U\left(Y_{L}, C^{j}, D^{j}, W\right)+f\left(Y_{L}, j, l\right) U\left(Y_{L}, D^{j}, R, W\right)
\end{aligned}
$$

In addition, a risk-decreasing technology i can be thought of as a substitute for weather insurance, or vice-versa. For instance, drought insurance and irrigation technology are expected to be substitutes, which can be formalized as follows:

$$
\begin{aligned}
& f\left(Y_{H}, i, h\right) U\left(Y_{H}-C^{i}+W\right)+f\left(Y_{H}, i, l\right) U\left(Y_{H}-C^{i}+W-M\right)+f\left(Y_{L}, i, h\right) U\left(Y_{L}-C^{i}+W\right) \\
& +f\left(Y_{L}, i, l\right) U\left(Y_{L}-C^{i}+W-M\right)=q U\left(Y_{T}-D(\gamma, \phi, W)+W\right)+(1-q) U\left(Y_{T}-D(\gamma, \phi, W)+R+W\right)
\end{aligned}
$$

where the left-hand side of Equation (6) redefines the expected utility for an uninsured farmer who adopted the technical change $i, U_{u}^{i}$, while the right-hand side is the expected utility when she decided not to adopt the technical change, but did buy rainfall insurance, $U_{I}^{T}$. Thus, the insurance-adoption decision for farmer $k$ can be simplified through the following indicator function, $d_{k}$ :

(7) $d_{k}(Y, C, D(\gamma, \phi, W), M, R, W)=\left\{\begin{array}{ll}1 & \text { If } U_{I, k}^{i}>U_{u, k}^{i} \text { or } U_{I, k}^{T}>U_{u, k}^{i} \\ 0 & \text { If } U_{u, k}^{i} \geq U_{I, k}^{i} \text { or } U_{u, k}^{i} \geq U_{I, k}^{T}\end{array} ; k=1,2, \ldots, m ; i=S, I, B\right.$

In addition, it is straightforward to show that the insurance adoption rate can be computed from the aggregation of individual decisions depicted by Equation (7). In this regard, many governments have committed to promoting farming insurance markets, even if this entails creating subsidies for farmers at taxpayers' expense. Despite such subsidies, the adoption of insurance among farmers is very limited, and insurance companies often fail to meet participation goals. In this regard, suppose that the government subsidizes crop insurance in order to promote hedging behavior among farmers. The subsidy reduces the amount of the insurance premium by $\alpha$ percent. 
Therefore, the insurance would be strictly preferred by the farmer if the following inequality holds:

$$
\begin{aligned}
& U_{u}^{i}<f\left(Y_{H}, i, h\right) U\left[Y_{H}-C^{i}-(1-\alpha) D(\gamma, \phi, W)+W\right]+f\left(Y_{H}, i, l\right) U\left[Y_{H}-(1-\alpha) D(\gamma, \phi, W)+R+W\right] \\
& \quad+f\left(Y_{L}, i, h\right) U\left[Y_{L}-C^{i}-(1-\alpha) D(\gamma, \phi, W)+W\right]+f\left(Y_{L}, i, l\right) U\left[Y_{L}-(1-\alpha) D(\gamma, \phi, W)+R+W\right]
\end{aligned}
$$

Under this scenario, the subsidy will encourage participation in the insurance program, particularly amongst farmers who were indifferent before this public policy was in force, i.e., $d_{k}=0$ for some farmer $k$.

The relationship between insurance and technological decisions is determined by the technological risk $\gamma$ and the farmer's knowledge of this risk. If the insurer knows the technological risk, then lower risk will reduce the amount of the premium. Hence, the probability of insurance adoption will be larger among farmers who implement a riskdecreasing technology (e.g., enhanced irrigation). This is valid provided there are no information asymmetries. Conversely, if $\gamma$ is not observable, then the insurer is unable to properly assess the differences in the risk profile of individual farmers and therefore charges a relatively high "average risk" insurance premium to all farmers. This flat-rate policy introduced by insurance companies will exacerbate the adverse selection issue. Specifically, there are economic incentives for crop insurance adoption among farmers who use risk-increasing technologies. In addition, farmers who adopt risk-decreasing technologies are less likely to claim large indemnities. Nonetheless, the premium that insurers charge to these farmers will be the average premium, which is too high for their risk profile, making it less attractive for them to adopt insurance.

\section{Data}

This study uses data from the 7th National Agriculture and Forestry Census (INE 2007). ${ }^{2}$ This survey constitutes the main data source on the current state of agricultural and forestry resources and rural population in Chile. Data collection is done in rural areas of the 15 regions of the country, covering 256,711 agricultural producers spread across

\footnotetext{
2 The Agricultural and Forestry Census is conducted each 10 years. The previous census was carried out in 1997. To our knowledge, the 2007 Census was not designed to be able to track a sub-sample of rural households from the previous round. Therefore, we cannot control for unobserved time-invariant effects as is required when using difference in difference techniques. However, it is highly likely that structural changes differently affecting irrigators and non-irrigators, which would make difference in difference methods problematic, have taken place over this period.
} 
the whole national territory. In particular, the survey collects information on households' demographic characteristics, assets, saving, credit, extension services, production, farm inputs, technology use, and public support instruments. Data is collected at the household and plot level, and can be combined with physical variables defined by location, such as soil and climate characteristics.

The census data allows us to explore differences between family farmers and nonfamily farmers. To distinguish each group, we employed a criterion based on size, which is used by the Ministry of Agriculture to focus public policy. This criterion defines family farmers as those who hold 12 or fewer hectares of basic irrigation (HBI). This requires transforming information about irrigated and dry land into HBI by using coefficients of conversion that capture differences in soil quality across zones. For these purposes, and following FAO (2009), we utilize the coefficients defined in Law 16.640 enacted in 1967 under the agrarian reform.

A sample of farmers who report growing wheat was selected, resulting in a sample of 42,531 observations, of which 39,874 are classified as family farmers, and 2,642 observations as non-family farmers. To measure crop insurance decisions, we use self-reports on insurance adoption. To explain these decisions, we use a series of control variables, including a dummy denoting whether the farmer is male; the farmer's age; the farmer's level of education; a categorical variable that captures the degree of dependence on agricultural activity; a dummy variable indicating whether the farmer lives on the plot; a capital measure based on availability of agricultural machinery and tools; ${ }^{3}$ the farm's size measured in total hectares; yield; security of tenure, measured by the ratio between the sum of family-owned and rental land hectares over total hectares; a dummy variable indicating whether the farmer had access to at least one of the following credit alternatives during the last two years: loans from INDAP, ${ }^{4}$ loans from the state bank, loans from private banks, or a credit line from either input providers or agro-industry; a dummy variable indicating participation in any agricultural organization; a dummy

\footnotetext{
${ }^{3}$ The capital variable was built using information with respect to ownership of draft mechanical capital. This was weighted by applying the principal component method. For the construction of the capital variable, the following tools and machinery were considered: ploughs, trucks, vans, carts, choppers, harvesters, cultivators, zero tillage, spray machines, harrows, rakes, reapers, seeders, hoppers, and tractors.

${ }^{4}$ The National Institute for Agricultural Development (INDAP) is a public and decentralized agency created to combat poverty and increase competitiveness among small-scale farmers in Chile through actions aimed at strengthening human, physical and financial capital.
} 
variable denoting whether the farmer received extension services during the last two years; percentage of non-eroded and slightly eroded soil; ${ }^{5}$ rainfall measured in millimeters; ${ }^{6}$ number of insurance adopters per locality regardless of crops; and a set of dummy variables to control for unobserved spatial differences across zones. ${ }^{7}$

As previously mentioned, to study the relationship between crop insurance and technology decisions, we focused on three key technologies: improved seed $(S)$, modern irrigation $(I)$ and biological control $(B)$. The purchase of improved seeds provides a determined crop variety with uniform germination and resistance to disease, which may increase yield and quality. Biological control promotes the use and combination of natural factors and agricultural practices to prevent damage caused by pests while minimizing human health risk and collateral effects on non-targeted organisms and the environment. Finally, the adoption of modern irrigation is an alternative to increase effectiveness in water application and improve crop productivity. We expect a strong interaction of modern irrigation with insurance decisions because both are climate riskdecreasing strategies. In contrast, while the adoption of improved seed may somewhat relate to climate risk and thus to insurance decisions, the take-up of biological control is less likely to be affected by climate considerations.

Table 1 presents the descriptive statistics of the insurance variable, technologies and control variables that are used in the estimations.

The average wheat yield reaches around 2,800 kilos per hectare. Large farmers almost double the yield observed among family farmers, suggesting a significant gap between small and large-scale producers in the agriculture sector in Chile. The figures suggest a low level of insurance and technology adoption, especially among family farmers. Only $2 \%$ of wheat farmers report using crop insurance, a proportion that is slightly reduced to $1.5 \%$ in the family farmer group. Insurance participation is greater among non-family farmers, amounting to $12 \%$ of the total. The use of new technology is

\footnotetext{
${ }^{5}$ Soil characteristics were proxied using information on soil erosion that was obtained from the Center for Information on Natural Resources (CIREN 2010). The methodology for determining the level of erosion integrates a set of soil, topographic, climatic, and biological characteristics. Thus, erosion will be more severe where soils are more porous and sandier and where fields are more sloped and hold less vegetation, as well as in locations where a large amount of rain falls in a short time.

${ }^{6}$ Cumulative precipitation was calculated using information provided by the agro-climatic system FDFINIA-DMC. Climate measures per locality were obtained by matching localities with the nearest meteorological station.

${ }^{7}$ Farm location was controlled by distinguishing the northern zone, comprising Regions IV and V; central zone, including Regions XIII, VI, and VII; and southern zone, consisting of Regions VIII, IX, X, and XIV.
} 
also low and less widespread among family farmers relative to larger farmers. Modern irrigation and biological control adoption do not surpass 5\% of total wheat farmers. Improved seed is more broadly used among wheat producers. While $18 \%$ of the family farmers report purchasing certified seeds, this figure surpasses $60 \%$ amongst larger farmers. The use of certified seeds depends on a purchase decision whose benefits are more evident in the short term. In contrast, biological control and modern irrigation adoption involve investment decisions with unknown potential benefits in the long run.

Regarding farmers' characteristics and the institutional setting in which they operate, it was observed that schooling rates are rather low; in fact, most family farmers do not manage to surpass the primary educational level. In addition, only $8 \%$ of farmers report having used credit instruments. In relation to extension services, $22.6 \%$ of family farmers have received this kind of government support in the last two years, which compares to the $14 \%$ observed among larger wheat producers. Around $20 \%$ of wheat farmers participate in organizations. This figure is larger among non-family wheat farmers, amounting to 45\%. Regarding land property status, $85 \%$ of total land corresponds either to own land with a registered title or to rented land, compared with farmers with less secure land tenancy. This percentage is also larger among large-scale farmers.

\section{Empirical Strategy}

\subsection{Adoption of Agricultural Insurance When Technology Decisions Are Exogenous}

As a first empirical approach, we begin by investigating the determinants of the adoption of agricultural insurance, assuming that farmers' choices are exogenous to technology decisions. In line with the theoretical framework, the probability that farmer $i$ has her production insured is given by:

$$
\text { (9) } P\left(y_{i}=1 \mid z_{i}, x_{i}\right)=\Phi\left(z_{i} \gamma, x_{i} \beta\right)
$$

where yi is a dummy variable indicating the adoption status of farmer $i$ in the year under study, zi is a vector of observed covariates at the farmer level (e.g., socioeconomic characteristics, dependence on on-farm work), farm level characteristics (including institutional aspects), and the regional factors (e.g., environmental characteristics, location). Similarly, xi is a vector of input production technologies adopted by farmer $\mathrm{i}$ 
(e.g., improved seed, biological control, and modern irrigation), which here are assumed to be exogenous to adoption decisions; $\gamma$ and $\beta$ are vectors of the parameters to be estimated; and $\Phi$ is the normal cumulative density function. We are particularly interested in the direction and magnitude of $\beta$, which will shed light on the extent to which input production technologies on the farm relate to the adoption of agricultural insurance, when either decision is assumed to be independent of the other. Therefore, the purpose of this baseline specification is to illustrate the extent to which the effects captured by $\beta$ are biased when joint decisions (whenever present) are not addressed. This equation is estimated by means of univariate probit models.

\subsection{Adoption of Agricultural Insurance and Technology When Farmers' Decisions Are Jointly Made}

We next investigate the extent to which the adoption of agricultural insurance is associated with the adoption of input production technologies that could be perceived by farmers as either risk-increasing or decreasing; that is to say, these decisions now are allowed to be interrelated. Specifically, we model the adoption of agricultural insurance, assuming that farmers' adoption decisions are related through some unobservable channel. Thus, farmers' decisions can be represented as follows:

$$
\text { (10) } \begin{aligned}
y_{1}^{*} & =x_{2}^{*} \beta+z_{1} \gamma+\varepsilon_{1} \\
x_{2}^{*} & =z_{2} \gamma+\varepsilon_{2}
\end{aligned}
$$

where $y_{1}{ }^{*}$ and $x_{2}{ }^{*}$ are unobservable and related to the binary dependent variables $y_{i}$ according to the rule:

$$
\text { (11) } y_{i}=\left\{\begin{array}{ll}
1 & \text { if } y_{i}^{*}>0 \\
0 & \text { if } y_{i}^{*} \leq 0
\end{array} ; y_{i}{ }^{*}=y_{1}{ }^{*}, x_{2}{ }^{*}\right.
$$

Specifically, $\mathrm{y}_{\mathrm{i}}$ are binary variables denoting the adoption of agricultural insurance and agricultural technologies, respectively. Similarly, z1 and z2 denote the vectors of explanatory variables explaining farmers' decisions regarding the adoption of agricultural insurance and agricultural technologies, respectively. There are no constraints regarding the covariates embedded in $\mathrm{z} 1$ and $\mathrm{z} 2$. The most important feature of this model, however, is the relationship between the error terms. In particular, if the error terms in the equations above are independent of one another, i.e., $\operatorname{Cov}[\varepsilon 1, \varepsilon 2]=0$, then the model can be estimated by means of two separate probit regressions. This would give us an indication that farmers’ decisions are independent. By contrast, if the error 
terms are interrelated, it will be the case that $\operatorname{Cov}[\varepsilon 1, \varepsilon 2] \neq 0$, and farmers’ decisions will be driven by the same underlying process. To take account of the relationship between these processes, the error terms above can be represented as follows:

$$
\begin{aligned}
& \varepsilon_{1 i}=\eta_{i}+u_{1 i} \\
& \varepsilon_{2 i}=\eta_{i}+u_{2 i}
\end{aligned}
$$

It can be seen from Equation (12) that, while there is a component of the error term that is unique to each equation, there is another component that is common to both. This term allows us to capture the relationship between the equations (Greene 1999). If it is assumed that the error terms are normally distributed, then $\varepsilon 1$ and $\varepsilon 2$ will not only be normal but also dependent. Let us further assume that $\rho$ denotes the extent to which these errors are correlated. Because of our interest in the joint probability of yi (i.e., y1 and x2), and because of the assumption that the error terms are normally distributed, the equations above can be consistently estimated by means of bivariate probit models. The significance of the coefficient $\rho$ will provide information on whether or not insurance and technology decisions are interrelated. If $\rho$ is not statistically significantly different from zero, the underlying process of the insurance decision is more likely to be characterized by Equation (9).

\section{Results}

We first discuss the results obtained from probit model estimations, neglecting the potential interactions between technologies and insurance decisions. Then, we analyze bivariate probit models that account for this relationship.

\subsection{Adoption of Agricultural Insurance}

Estimation of the insurance decision process using the probit model is depicted in Table 2. Results report the estimated coefficients for Equation (9). The first column depicts the estimates using the sub-sample of family farmers. Column (2) shows the estimated parameters for the non-family segment.

Regardless of the sample chosen, dependence, yield, capital, extension, credit access, participation, number of adopters and rainfall are statistically significant to explain adoption of crop insurance. We find that farmers who are more agricultural 
income-dependent are more likely to adopt insurance. 8 Given that insurance covers losses from unpredictable weather events, farmers obtaining a larger proportion of their income from agriculture would be more inclined to buy crop insurance. A related explanation considers the extent of diversification into non-agricultural activities. Mohammed and Ortmann (2005) find that alternative risk management strategies, such as off-farm investments, reduce the probability of agricultural insurance adoption. Similarly, Richards (2000) find a negative relationship between the extent of diversification into livestock and the tendency to insure crops. Results also confirm that farmers with higher yields have higher probabilities of participating in the insurance program. Market return and return to insurance variables also have been found important in previous literature (Coble et al. 1996; Cabas et al. 2008; Garrido and Zilberman 2008). Extension services were also found important in explaining insurance decisions.

Capital significantly and positively affects insurance adoption. This is somewhat unexpected in light of evidence that farmers' risk aversion decreases as their wealth increases; therefore, wealthier farms should be less likely to insure (Serra et al. 2003). However, larger wealth size may promote the adoption of instruments to cover against higher potential losses (Santeramo et al. 2016).

We find that support from government agencies is crucial, which is an expected finding, given that it is difficult for family farmers to afford insurance premiums. We also find that farmers who reported having access to credit are more likely to adopt insurance. In addition, results show that farmers participating in agrarian organizations are more likely to use insurance. Participation in organizations may serve as a vehicle for transmission and diffusion of knowledge about financial instruments to protect against risk or face new market conditions. The number of adopters of insurance at the local level is also significant. The latter may be associated with potential learning effects among farmers who belong to related networks or adjacent geographical areas.

We also find evidence of differences in adoption due to variations in precipitation across locations. In particular, insurance is more broadly adopted in drier zones, as

\footnotetext{
${ }^{8}$ Multicollinearity is always a concern. For example, education is most likely highly correlated with income variables; capital and land can ease access to credit; etc. We evaluate a potential correlation among suspicious variables in two ways: First, we report correlation coefficients of the suspicious variables. We obtain a coefficient of 0.12 for land and credit, 0.35 for land and capital and 0.12 for dependence on agriculture and capital. These correlations suggest that multicollinearity is not an important issue. Second, we simply drop the suspicious variables and explore the sensitivity of the results to the exclusion of these variables. Results do not change fundamentally. The results of these tests are available upon request.
} 
expected. This result is in line with the usual findings that higher-risk farms are more likely to be insured (Enjolras and Sentis 2011). For the family farmers segment, we additionally find that the variables age, residence on the farm, and farm size matter. Age negatively influences the probability of adopting insurance. It is likely that older farmers are more reluctant to try non-traditional instruments, in particular, financial instruments whose benefits are little known or difficult to perceive by more conservative family farmers. Sherrick et al. (2003) also find that those preferring revenue insurance are younger. Regarding residence on the farm, farmers who live on the farm may be more exposed to diffusion because interactions and networks are strengthened with reduced mobility.

We find that the larger the farm, the more probable the adoption of insurance. Undoubtedly, the cost-benefit ratios of adopting insurance are better when there is a larger crop area to protect, given the high administrative costs of insurance. In addition, growers with operations spread over large areas may benefit from geographical diversification (Richards 2000; Sherrick et al. 2004; Santeramo et al. 2016). Education and secure tenure variables seem to be more important among non-family farmers. Education is positively associated with insurance. Thus, education may turn out to be a complement to insurance when it is knowledge intensive and when benefits are linked to farmers' management capacity. Farmers who hold a larger ratio of both owned land and land under property rental contracts (which provide relatively secure tenure) are more likely to buy insurance. This fact confirms the importance of designing tenancy arrangements that guarantee rights to enjoy long-term benefits derived from farm economic activities.

There were some discrepancies in the results concerning the soil quality variable. While good soil quality was important in promoting insurance adoption among family farmers, insurance was more likely to be observed among non-family farmers in locations with poorer soil conditions.

Concerning technology adoption, the findings reveal a positive association between the three technologies under study and the probability of adopting insurance, irrespective of the sample used (only biological control is insignificant in the family farmer sample, although the coefficient is positive). In other words, the greater the adoption of technologies, the higher the probability that farmers will participate in the crop insurance program. The latter may be in line with arguments based on the riskincreasing effects of adopting new technologies. Nevertheless, these estimations do not 
take into consideration interactions between the insurance and technology adoption processes.

\subsection{Technology Adoption and Agricultural Insurance}

Tables 3 and 4 present the main results of the bivariate probit regressions for the sub-samples of family farmers and non-family farmers, respectively. Columns (1)-(2) display farmers' decisions regarding the adoption of agricultural insurance and certified seed. Similarly, farmers' decisions regarding the adoption of agricultural insurance and biological control are depicted in Columns (3)-(4). Columns (5)-(6) present estimated parameters associated with the interplay between adoption of agricultural insurance and modern irrigation. Estimated coefficients suggest a number of findings that are worth mentioning.

First, there is evidence that family farmers' decisions are interrelated, regardless of the production technology under analysis. This finding is supported by the fact that the athrho coefficient $(\rho)$ is positive and statistically significant at the $1 \%$ level for all the technologies, indicating that both decisions are indeed linked. Consequently, farmers' decisions should be analyzed by means of a bivariate model. In contrast, the estimated coefficient of athrho $(\rho)$ was statistically insignificant among non-family farmers, indicating that the decisions are independent. This suggests that the determinants of production decisions may differ between the two groups, probably because of the differences in risk coping strategies that are available to farmers.

Second, while adoption of certified seed by farmers in either sub-sample has no effect on the probability of being insured, both biological control and modern irrigation negatively affect the probability of being insured in the sub-sample of family farmers. This differs from the results in the univariate model. The result for biological control was somewhat unexpected because agricultural insurance protects farmers against climatic risks exclusively and not from losses due to pest infection and other production shocks. In contrast, the finding that a farmer adopting modern irrigation is less likely to adopt agricultural insurance is in line with Foudi and Erdlenbruch (2012). This implies that modern irrigation can be understood as a substitute for agricultural insurance (i.e., both insurance and modern irrigation protect farmers against climatic risks such as droughts), suggesting a high insurance participation rate among higher risk profile farms, which can be taken as evidence of adverse selection. 


\section{Robustness Checks}

\subsection{Adoption Decisions in Homogeneous Areas}

It was pointed out in the sections above that agro-climatic conditions in Chile exhibit a great deal of heterogeneity. Because availability of water sources, soil nutrients, and other geographical characteristics affecting agricultural activity significantly change when moving from north to south, it might be thought that farmers' choices regarding participation in the climate risk insurance program are mainly driven by geography. In order to evaluate the sensitivity of the results to exposure to given agro-climatic characteristics, we estimate the bivariate probit model in Equations (10)-(12) on a subsample of farmers located in Central Chile. By construction, farmers in this sub-sample are located in more homogeneous zones. Estimated coefficients are displayed in Table A1, Appendix A. As can be seen, results are robust for modern irrigation technology and less clear for biological control, in that its relationship with insurance becomes insignificant.

\subsection{Assessing Technological Change among Irrigators}

So far, the uptake of agricultural insurance by farmers adopting modern irrigation has been analyzed using the totality of farmers. Because an important number of farmers do not irrigate, we might be comparing two groups of farmers that are systematically different (i.e., irrigators and non-irrigators). In order to account for the technological change due to the shift from traditional to modern irrigation, the analysis was constrained to the sample of irrigators. Results are shown in Table A2, Appendix A. As can be seen, the sign and statistical significance of the estimated coefficient of modern irrigation technology on insurance participation remained robust to the exclusion of non-irrigators. Nonetheless, results did not hold for farmers adopting biological pest control.

\subsection{Controlling for Multiple Relationships}

In the results above, relationships between crop insurance and technology decisions were considered individually, assuming no correlation among different technologies. However, relationships among technologies may be important. To account for this, we estimate a multivariate probit model on the sub-sample of family famers and irrigators for the central zone. Results are shown in Table A3, Appendix A, and confirm the significant relationship between insurance adoption and modern irrigation decisions. However, the relationship between insurance adoption and biological control becomes 
insignificant. Accordingly, we find that the probability of adopting insurance is lower among modern irrigators. We additionally find evidence of relationships between certified seeds and biological control technologies. Thus, results remained robust after controlling for multiple relationships.

\subsection{Instrumental Variable Approach}

The joint insurance takeup/agricultural technology adoption decision is estimated by means of bivariate probit models. The identification lies mainly in the structure of the model, which seems to overlook exclusion restriction considerations. Some authors argue that this is sufficient for identification (Wilde 2000). However, an IV approach might help in making the estimation results more robust to distributional misspecifications (Monfardini and Radice 2007). In this section, we apply an IV approach under the bivariate probit model. The systematic and strong significance of the athrho coeffient $(\rho)$ across different specifications in the insurance and modern irrigation model suggests that endogeneity may be problematic in this case. Consequently, we focus on the joint estimation of insurance and modern irrigation decisions. For identification, we exploit the characteristics of the water source used for irrigation. In particular, we assume that modern irrigation decisions respond to the availability of well water on the farm. Wasting water becomes much more costly when pumped from groundwater sources. In that case, the availability of expensive water sources may promote adoption of water-saving technologies (Caswell and Zilberman 1986). Results are presented in Table A4, Appendix A. They show that our instrument is strongly correlated with modern irrigation but does not affect the insurance decision. Overall, our key results still stand. Modern irrigation reduces the likelihood of adopting crop insurance, suggesting that Chilean farmers perceive these two options as substitutes.

\section{Conclusions}

Chile faces the challenge of transforming the Chilean agricultural sector into a world-wide agricultural production and food powerhouse (MINAGRI 2006). Furthermore, climate change studies estimate an increase in temperature and decline in precipitation along with an increasing demand for water resources, foreshadowing a higher drought risk for the coming decades in Chile (FAO 2010). Therefore, improvements in climate risk management by the adoption of modern technology and crop insurance are likely to become essential in order to reduce the vulnerability of agriculture in the future. This paper examined the interactions between crop insurance 
and technology adoption decisions among wheat farmers in Chile by using bivariate probit models. Results shed light on the importance of controlling for such relationships, suggesting that both decisions are jointly driven by the type of technology and the characteristics of farmers, among other factors. In particular, we found that relationships between insurance and technology decisions are strong and significant among family farmers, but not among large-scale farmers. In addition, the estimations of the bivariate probit model suggest that, whereas modern irrigation decisions are related to insurance participation, certified seed and biological control adoption are more likely to be independent of insurance decisions.

The empirical study provided evidence that modern irrigation reduces the likelihood of adopting crop insurance, suggesting that Chilean farmers perceive these two options as substitutes. The latter implies that farmers who cannot protect themselves against riskier situations, that is, those using traditional irrigation methods, preferentially participate in the insurance program, which can be taken as evidence of problems of adverse selection in the Chilean insurance market. These findings were found to be robust when reducing spatial variation and focusing on a more homogeneous agro-climatic zone. In addition, results were not driven by non-irrigators or by multiple technological decisions. Finally, the key results stand when implementing an instrumental variable approach.

Nevertheless, a couple of caveats deserve attention. First, given the crosssectional nature of the data, it was not possible to fully explore the dynamics of the relationship between insurance and technology decisions. These may be important, especially in examining the dynamic components embodied in exit and entry decisions in the insurance program (Cabas et al. 2008; Santeramo et al. 2016). Second, the database does not report information on some key control variables such as insurance premium, although it was proxied by including yield variables. Relatedly, the low participation rate in the crop insurance program may be due to a lack of competition on the supply side. The existence of only two insurance operators suggests the emergence of market concentration issues, which may increase insurance premiums and then reduce the power of subsidies as economic incentives for participation. Third, our main results assumed that irrigation and insurance decisions are homogeneous, independent of the type of risk. However, it may be the case that farmers who live in high drought risk environments react differently than those living in high flood risk areas. For example, irrigation may indeed smooth over risks in drought prone areas, but it may do the opposite in flood prone areas. In the former case, the model suggests insurance and irrigation will be 
substitutes, but in the latter they will be complements. Although we do have detailed information on main flood prone areas in Chile, this phenomenon does not seem to be a main concern in Chile, at least for agricultural production. By contrast, droughts are frequent and affect $25 \%$ of the continental territory (FAO 2010). Thus, it is more probable that irrigation and insurance are substitutes.

Despite these caveats, these findings have important implications for the success of government interventions to address the low participation rate in the insurance program. First, to optimize a policy instrument aimed at increasing insurance participation, it is necessary to understand the risk character of the technology. Farmers adopting modern irrigation clearly face less risk than do traditional irrigators, and therefore they should pay a lower premium. However, because premiums paid by modern irrigators essentially underwrite the program for traditional irrigators, the premium for modern irrigators may be so high that too few of them decide to buy insurance. It is probable that existing rigidity in the climate insurance program magnifies these market distortions. Insurance programs should be re-designed to allow greater flexibility in order to better match insurance utilization to other risk management practices.

Second, our results suggest the existence of relationships between insurance and technology decisions mainly among family farmers, and therefore highlight the importance of incorporating the particularity of the family farmers segment in the design of an improved insurance scheme. Although differences in access to insurance between family and non-family farmers justify larger subsidies for the first group, greater financial support for family farmers who have not adopted modern irrigation may be aggravating the adverse selection problem. One interesting aspect is how public policy in terms of insurance subsidies is contributing to these potential distortions in the Chilean crop insurance market. The latter is left for future research. 


\section{References}

Babcock, B., and D. Hennessy. 1996. Input Demand under Yield and Revenue Insurance. American Journal of Agricultural Economics 78(2): 416-427.

Barnett, B., J. Skees, and J. Hourigan. 1990. Explaining Participation in Federal Crop Insurance. American Journal of Agricultural Economics 72(5): 1375-1375.

Cabas, J., A. Leiva, and A. Weersink. 2008. Modeling Exit and Entry of Farmers in a Crop Insurance Program. Agricultural and Resource Economics Review 37(1): 92-105.

Caswell, M., and D. Zilberman. 1986. The Effects of Well Depth and Land Quality on the Choice of Irrigation Technology. American Journal of Agricultural Economics 68(4): 798-811.

CIREN. 2010. Determinación de la Erosión Actual y Potencial de los Suelos de Chile. Available at: http://www.ciren.cl (accessed 24-07-2017).

Coble, K., T. Knight, R. Pope, and J. Williams. 1996. Modeling Farm-level Crop Insurance Demand with Panel Data. American Journal of Agricultural Economics 78(2): 439-447.

COMSA. 2012. Informe Final. Programa Seguro Agrícola. Ministerio de Agricultura y Economía. Available at http://www.agroseguros.gob.cl (accessed 04-05-2016).

Dercon, S. 2002. Income Risk, Coping Strategies, and Safety Nets. World Bank Research Observer 17(2): 141-166.

Enjolras, G., and P. Sentis. 2011. Crop Insurance Policies and Purchases in France. Agricultural Economics 42(4): 475-486.

FAO. 2009. Evolución de la Agricultura Familiar Campesina en Chile en el Periodo 1997-2007. Food and Agriculture Organization of the United Nations (FAO). Representation in Chile.

FAO. 2010. Gestión del Riesgo de Sequía y Otros Eventos climáticos en Chile. Food and Agriculture Organization of the United Nations (FAO). Representation in Chile.

Foudi, S., and K. Erdlenbruch. 2012. The Role of Irrigation in Farmers’ Risk Management Strategies in France. European Review of Agricultural Economics 39(3): 439-457. 
Gardner, B., and R. Kramer. 1986. Experience with Crop Insurance Programs in the United States. Crop Insurance for Agricultural Development: Issues and Experience. Baltimore: Johns Hopkins University Press, pp. 195-222.

Garrido, A., and D. Zilberman. 2008. Revisiting the Demand for Agricultural Insurance: The Case of Spain. Agricultural Finance Review 68(1): 43-66.

Giné, X., and D. Yang. 2009. Insurance, Credit, and Technology Adoption: Field Experimental Evidence from Malawi. Journal of Development Economics 89(1): $1-11$.

Goodwin, B., M. Vandeveer, and J. Deal. 2004. An Empirical Analysis of Acreage Effects of Participation in the Federal Crop Insurance Program. American Journal of Agricultural Economics 86(4): 1058-1077.

Greene, W. 1999. Econometric Analysis. New York: Macmillan.

Hazell, P.B.R. 1992. The Appropriate Role of Agricultural Insurance in Developing Countries. Journal of International Development 4(6): 567-581.

Hojjati, B., and N. Bockstael. 1988. Modeling the Demand for Crop Insurance. Multiple Peril Crop Insurance: A Collection of Empirical Studies, edited by Harry P. Mapp. Southern Cooperative Series Bulletin No. 334. Oklahoma State University.

Horowitz, J., and E. Lichtenberg. 1993. Insurance, Moral Hazard, and Chemical Use in Agriculture. American Journal of Agricultural Economics 75(4): 926-935.

INDAP. 2011. Statistical Figures. Instituto de Desarrollo Agropecuario, Santiago, Chile. Available at http://portal.indap.cl_(accessed 04-05-2016).

INE. 2007. VII Censo Nacional Agropecuario y Forestal. Santiago, Chile: Instituto Nacional de Estadística (INE).

Just, R., L. Calvin, and J. Quiggin. 1999. Adverse Selection in Crop Insurance: Actuarial and Asymmetric Information Incentives. American Journal of Agricultural Economics 81(4): 834-849.

Makki, S., and A. Somwaru. 2001. Farmers' Participation in Crop Insurance Markets: Creating the Right Incentives. American Journal of Agricultural Economics 83(3): 662-667.

Ministerio de Agricultura (MINAGRI). 2006. Chile Potencia Alimentaria. Documento base para la Elaboración de una Agenda Pro-competividad. Ministerio de Agricultura. 
Mobarak, A., and M. Rosenzweig. 2012. Selling Formal Insurance to the Informally Insured. Yale Economics Department Working Paper No. 97, February. Available at: https://ssrn.com/abstract=2009528 (accessed 06-04-2017).

Mohammed, M., and G. Ortmann. 2005. Factors Influencing Adoption of Livestock Insurance by Commercial Dairy Farmers in Three Zobatat of Eritrea. Agrekon 44(2): 172-186.

Monfardini, C., and R. Radice. 2007. Testing Exogeneity in the Bivariate Probit Model: A Monte Carlo Study. Oxford Bulletin of Economics and Statistics 70(2): 271282.

Quiggin, J., G. Karagiannis, and J. Stanton. 1993. Crop Insurance and Crop Production: An Empirical Study of Moral Hazard and Adverse Selection. Australian Journal of Agricultural Economics 37(2): 95-113.

Richards, T. 2000. A Two-stage Model of the Demand for Specialty Crop Insurance. Journal of Agricultural and Resource Economics 25(1): 177-194.

Santeramo, F., B. Goodwin, F. Adinolfi, and F. Capitanio. 2016. Farmer Participation, Entry and Exit Decisions in the Italian Crop Insurance Programme. Journal of Agricultural Economics 67(3): 639-657.

Serra, T., B. Goodwin, B., and A. Featherstone. 2003. Modeling Changes in the U.S. Demand for Crop Insurance during the 1990s. Agricultural Finance Review 63(2): 109-125.

Sherrick, B., P. Barry, P. Ellinger, and G. Schnitkey. 2004. Factors Influencing Farmers' Crop Insurance Decisions. American Journal of Agricultural Economics 86(1): 103-114.

Sherrick, B., G.D. Schnitkey, P.N. Ellinger, P.J. Barry, and B. Wansink. 2003. Farmers Preferences for Crop Insurance Attributes. Review of Agricultural Economics 25(2): 415-429.

Smith, V., and B. Goodwin. 1996. Crop Insurance, Moral Hazard, and Agricultural Chemical Use. American Journal of Agricultural Economics 78(2): 428-438.

Vila, F., M. Otero, D. Hatch, and M. García-Winder. 2011. Gestión de Riesgos y Seguros Agrícolas en IICA: Relevamiento de Necesidades, Análisis de Demandas y Propuestas de Líneas de Acción. Informe del Programa de Agronegocios y 
Comercializalición del Instituto Interamericano de Cooperación para la Agricultura (IICA) March, 2011(March).

Wenner, M. 2005. Agricultural Insurance Revisited: New Developments and Perspectives in Latin America and the Caribbean. Inter-American Development Bank, Rural Development Unit. Working paper. http://www.iadb.org/sds/.

Wilde, J. 2000. Identification of Multiple Equation Probit Models with Endogenous Dummy Regressors. Economic Letters 69(3): 309-312.

Zorrilla, J. 2002. Extensive Herbaceous Cultivation and Cattle Risks: Possibilities that Agricultural Insurance Offers for their Management. International Conference: Agricultural Insurance and Income Guarantee. Madrid, May 13, 2002. 


\section{Tables}

Table 1. Descriptive Statistics of Major Explanatory Variables (Type of Farmer)

\begin{tabular}{|c|c|c|c|c|c|c|}
\hline \multirow{2}{*}{ Category } & \multicolumn{2}{|c|}{ Total } & \multicolumn{2}{|c|}{ Family } & \multicolumn{2}{|c|}{ Non-family } \\
\hline & Mean & Std & Mean & Std & Mean & Std \\
\hline Crop insurance & 0.022 & 0.148 & 0.015 & 0.122 & 0.120 & 0.325 \\
\hline \multicolumn{7}{|l|}{ Socioeconomic variables } \\
\hline Age & 57.89 & 14.462 & 57.816 & 14.458 & 59.017 & 14.491 \\
\hline Male & 0.753 & 0.431 & 0.751 & 0.433 & 0.796 & 0.403 \\
\hline Reside in Plot & 0.748 & 0.434 & 0.772 & 0.420 & 0.441 & 0.497 \\
\hline Education & 1.909 & 1.761 & 1.784 & 1.609 & 3.806 & 2.655 \\
\hline Dependence & 1.411 & 1.219 & 1.371 & 1.214 & 1.940 & 1.176 \\
\hline \multicolumn{7}{|l|}{ Institutional variables } \\
\hline Credit & 0.084 & 0.277 & 0.060 & 0.237 & 0.394 & 0.489 \\
\hline Secure tenure (\% hectares) & 0.851 & 0.329 & 0.843 & 0.337 & 0.948 & 0.196 \\
\hline Extension services & 0.220 & 0.414 & 0.226 & 0.419 & 0.141 & 0.348 \\
\hline Participation in organizations & 0.204 & 0.403 & 0.184 & 0.388 & 0.457 & 0.498 \\
\hline Number insurance adopters & 25.374 & 35.352 & 24.641 & 34.875 & 34.781 & 39.801 \\
\hline \multicolumn{7}{|l|}{ Farm size } \\
\hline Yield (kilos per hectare) & 2814.4 & 3315.3 & 2682.4 & 3349.4 & 4505.5 & 2234.5 \\
\hline Total surface (hectares) & 38.063 & 194.71 & 17.199 & 22.458 & 305.503 & 663.655 \\
\hline Capital & 0.083 & 1.208 & -0.092 & 0.585 & 2.317 & 3.226 \\
\hline \multicolumn{7}{|l|}{ Technology adoption } \\
\hline Certified seed & 0.213 & 0.409 & 0.180 & 0.384 & 0.628 & 0.483 \\
\hline Biological control & 0.038 & 0.191 & 0.030 & 0.170 & 0.142 & 0.350 \\
\hline Modern irrigation & 0.050 & 0.218 & 0.041 & 0.198 & 0.171 & 0.377 \\
\hline \multicolumn{7}{|l|}{$\begin{array}{l}\text { Environmental and location } \\
\text { variables }\end{array}$} \\
\hline Rainfall (millimeters) & 911.195 & 327.369 & 917.788 & 323.163 & 826.687 & 366.860 \\
\hline Soil quality (ratio) & 0.283 & 0.189 & 0.283 & 0.186 & 0.289 & 0.223 \\
\hline \multicolumn{7}{|l|}{ Location variables } \\
\hline North zone & 0.007 & 0.081 & 0.005 & 0.073 & 0.024 & 0.153 \\
\hline Central zone & 0.159 & 0.366 & 0.145 & 0.352 & 0.352 & 0.478 \\
\hline South zone & 0.833 & 0.373 & 0.850 & 0.357 & 0.624 & 0.485 \\
\hline Observations & \multicolumn{2}{|c|}{42,531} & \multicolumn{2}{|c|}{39,874} & \multicolumn{2}{|c|}{2,642} \\
\hline
\end{tabular}

Source: Own elaboration based on census data, 2007. 
Table 2. Estimates of the Probit Model for Insurance Adoption

\begin{tabular}{|c|c|c|}
\hline Variables & Family farmers (1) & Non-family farmers (2) \\
\hline \multicolumn{3}{|c|}{ Technology } \\
\hline \multirow[t]{2}{*}{ Certified seed } & $0.476 * * *$ & $0.180 *$ \\
\hline & $(0.0433)$ & $(0.0964)$ \\
\hline \multirow[t]{2}{*}{ Biological control } & 0.0920 & $0.290 * * *$ \\
\hline & (0.0799) & $(0.0952)$ \\
\hline \multirow[t]{2}{*}{ Modern irrigation } & $0.136^{*}$ & $0.186^{* *}$ \\
\hline & $(0.0808)$ & $(0.0937)$ \\
\hline \multicolumn{3}{|c|}{ Household and farm characteristics } \\
\hline \multirow[t]{2}{*}{ Gender (Male=1) } & 0.0544 & -0.0503 \\
\hline & $(0.0494)$ & $(0.0859)$ \\
\hline \multirow[t]{2}{*}{ Age } & $-0.00600 * * *$ & -0.00310 \\
\hline & $(0.00147)$ & $(0.00273)$ \\
\hline \multirow[t]{2}{*}{ Reside on farm } & $-0.233 * * *$ & -0.0382 \\
\hline & $(0.0479)$ & $(0.0744)$ \\
\hline \multirow[t]{2}{*}{ Education } & 0.0131 & $0.0322 * *$ \\
\hline & $(0.0117)$ & $(0.0154)$ \\
\hline \multirow[t]{2}{*}{ Dependence } & $0.113^{* * *}$ & $0.0593 *$ \\
\hline & $(0.0180)$ & $(0.0335)$ \\
\hline \multirow[t]{2}{*}{ Capital } & $0.130 * * *$ & $0.0445^{* * *}$ \\
\hline & $(0.0208)$ & $(0.0127)$ \\
\hline \multirow[t]{2}{*}{ Land } & $0.00211 * * *$ & $0.000122 *$ \\
\hline & $(0.000792)$ & $(7.25 e-05)$ \\
\hline \multirow[t]{3}{*}{ Yield } & $0.000587 * * *$ & $0.00789 * * *$ \\
\hline & $(0.000192)$ & $(0.00196)$ \\
\hline & Institutional variab & \\
\hline \multirow[t]{2}{*}{ Secure tenure } & 0.104 & $0.342 *$ \\
\hline & $(0.0690)$ & $(0.206)$ \\
\hline \multirow[t]{2}{*}{ Extension } & $0.399 * * *$ & $0.347 * * *$ \\
\hline & $(0.0440)$ & $(0.0997)$ \\
\hline \multirow[t]{2}{*}{ Credit } & $0.855^{* * *}$ & $0.592 * * *$ \\
\hline & $(0.0464)$ & $(0.0776)$ \\
\hline \multirow[t]{2}{*}{ Participation } & $0.167 * * *$ & $0.217^{* * *}$ \\
\hline & $(0.0438)$ & $(0.0762)$ \\
\hline \multirow[t]{2}{*}{$\mathrm{N}^{\circ}$ adopters } & $0.00864 * * *$ & $0.00479 * * *$ \\
\hline & $(0.000448)$ & $(0.000822)$ \\
\hline \multicolumn{3}{|c|}{ Environmental and location variables } \\
\hline \multirow[t]{2}{*}{ Rainfall } & $-0.000207^{* *}$ & $-0.000385^{* * *}$ \\
\hline & $(8.08 \mathrm{e}-05)$ & $(0.000140)$ \\
\hline \multirow[t]{2}{*}{ Soil quality } & $0.595 * * *$ & $-0.508 * *$ \\
\hline & $(0.133)$ & $(0.245)$ \\
\hline \multirow[t]{2}{*}{ North zone } & & -0.135 \\
\hline & & $(0.408)$ \\
\hline \multirow[t]{2}{*}{ Central zone } & $-0.242 * * *$ & -0.129 \\
\hline & $(0.0696)$ & $(0.112)$ \\
\hline \multirow[t]{2}{*}{ Constant } & $-2.905 * * *$ & $-2.500 * * *$ \\
\hline & $(0.137)$ & $(0.348)$ \\
\hline Obs. & 39,874 & 2,642 \\
\hline
\end{tabular}

Note: Robust standard errors in parentheses. ${ }^{* * *} \mathrm{p}<0.01,{ }^{* *} \mathrm{p}<0.05,{ }^{*} \mathrm{p}<0.1$. 
Table 3. Estimates of the Bivariate Probit Model for Insurance Adoption (Family Farmers)

\begin{tabular}{|c|c|c|c|c|c|c|}
\hline Variables & $\begin{array}{c}\text { Insurance } \\
\text { (1) }\end{array}$ & $\begin{array}{l}\text { Certified } \\
\text { seed } \\
(2) \\
\end{array}$ & $\begin{array}{c}\text { Insurance } \\
\text { (3) }\end{array}$ & $\begin{array}{c}\text { Biological } \\
\text { control } \\
(4)\end{array}$ & $\begin{array}{c}\text { Insurance } \\
\text { (5) }\end{array}$ & $\begin{array}{l}\text { Modern } \\
\text { irrigation } \\
(6)\end{array}$ \\
\hline & \multicolumn{6}{|c|}{ Technology } \\
\hline \multirow[t]{2}{*}{ Certified seed } & 0.0296 & & $0.256 * * *$ & & $0.222 * * *$ & \\
\hline & $(0.178)$ & & $(0.0727)$ & & $(0.0323)$ & \\
\hline \multirow{2}{*}{$\begin{array}{l}\text { Biological } \\
\text { control }\end{array}$} & 0.0899 & & $-1.477^{* * *} *$ & & 0.0511 & \\
\hline & $(0.0782)$ & & $(0.0563)$ & & $(0.0444)$ & \\
\hline \multirow{3}{*}{$\begin{array}{l}\text { Modern } \\
\text { irrigation }\end{array}$} & $0.132 *$ & & 0.0554 & & $-1.573^{* * *}$ & \\
\hline & $(0.0792)$ & & $(0.0490)$ & & $(0.0526)$ & \\
\hline & \multicolumn{6}{|c|}{ Household and farm characteristics } \\
\hline \multirow{2}{*}{$\begin{array}{l}\text { Gender } \\
(\text { Male=1) }\end{array}$} & 0.0655 & $0.0715 * * *$ & 0.0406 & 0.0129 & $0.0571^{*}$ & 0.0246 \\
\hline & $(0.0484)$ & $(0.0184)$ & $(0.0330)$ & $(0.0307)$ & $(0.0315)$ & $(0.0278)$ \\
\hline Age & $\begin{array}{c}-0.00593 * * * \\
(0.00145)\end{array}$ & $\begin{array}{l}-0.000191 \\
(0.000565)\end{array}$ & $\begin{array}{c}-0.00263 * * \\
(0.00132)\end{array}$ & $\begin{array}{c}0.000936 \\
(0.000966)\end{array}$ & $\begin{array}{c}-0.00487 * * * \\
(0.000964)\end{array}$ & $\begin{array}{c}-0.00257^{* * *} \\
(0.000854)\end{array}$ \\
\hline \multirow[t]{2}{*}{ Reside on farm } & $-0.237 * * *$ & $-0.0514 * *$ & $-0.206 * * *$ & $-0.120 * * *$ & $0.0779 * *$ & $0.334 * * *$ \\
\hline & $(0.0470)$ & $(0.0201)$ & $(0.0371)$ & $(0.0329)$ & $(0.0389)$ & $(0.0370)$ \\
\hline \multirow[t]{2}{*}{ Education } & $0.0231^{*}$ & $0.0646 * * *$ & $0.0309 * * *$ & $0.0384 * * *$ & $0.0440 * * *$ & $0.0602 * * *$ \\
\hline & $(0.0123)$ & $(0.00467)$ & $(0.00822)$ & $(0.00739)$ & $(0.00794)$ & $(0.00714)$ \\
\hline \multirow[t]{2}{*}{ Dependence } & $0.122 * * *$ & $0.0720 * * *$ & 0.0101 & $-0.0764 * * *$ & $0.121 * * *$ & $0.100 * * *$ \\
\hline & $(0.0178)$ & $(0.00671)$ & $(0.0245)$ & (0.0129) & $(0.0115)$ & $(0.00991)$ \\
\hline \multirow[t]{2}{*}{ Capital } & $0.167 * * *$ & $0.259 * * *$ & $0.194^{* * *}$ & $0.189 * * *$ & $0.121^{* * *}$ & $0.0638 * * *$ \\
\hline & $(0.0238)$ & $(0.0178)$ & $(0.0172)$ & (0.0183) & $(0.0166)$ & $(0.0200)$ \\
\hline \multirow[t]{2}{*}{ Land } & $0.00226 * * *$ & $0.00122 * * *$ & $0.00199 * * *$ & $0.00117 * *$ & $0.00164 * * *$ & $-2.70 \mathrm{e}-05$ \\
\hline & $(0.000785)$ & $(0.000383)$ & $(0.000586)$ & (0.000585) & $(0.000546)$ & $(0.000564)$ \\
\hline Yield & $\begin{array}{c}0.000578 * * * \\
(0.000190)\end{array}$ & & $\begin{array}{c}0.000482 * * \\
(0.000209)\end{array}$ & & $\begin{array}{c}0.000519 * * * \\
(0.000200)\end{array}$ & \\
\hline
\end{tabular}




\begin{tabular}{|c|c|c|c|c|c|c|}
\hline \multirow{2}{*}{ Secure tenure } & \multicolumn{6}{|c|}{ Institutional variables } \\
\hline & $0.117^{*}$ & $0.0909 * * *$ & 0.0726 & 0.0127 & $0.0766^{*}$ & 0.0285 \\
\hline & $(0.0680)$ & $(0.0248)$ & $(0.0474)$ & $(0.0431)$ & $(0.0428)$ & $(0.0354)$ \\
\hline \multirow[t]{2}{*}{ Extension } & $0.435 * * *$ & $0.282 * * *$ & $0.322 * * *$ & $0.162^{* * *}$ & $0.508 * * *$ & $0.486 * * *$ \\
\hline & $(0.0440)$ & $(0.0183)$ & $(0.0455)$ & $(0.0314)$ & $(0.0280)$ & $(0.0247)$ \\
\hline \multirow[t]{2}{*}{ Credit } & $0.918 * * *$ & $0.498 * * *$ & $0.757 * * *$ & $0.461 * * *$ & $0.632 * * *$ & $0.305^{* * *}$ \\
\hline & $(0.0492)$ & $(0.0299)$ & $(0.0590)$ & $(0.0476)$ & $(0.0402)$ & $(0.0432)$ \\
\hline \multirow[t]{2}{*}{ Participation } & $0.212^{* * *}$ & $0.306^{* * *}$ & $0.346 * * *$ & $0.413^{* * *}$ & $0.102 * * *$ & 0.0299 \\
\hline & $(0.0453)$ & $(0.0188)$ & $(0.0349)$ & $(0.0306)$ & $(0.0302)$ & $(0.0291)$ \\
\hline \multirow[t]{3}{*}{$\mathrm{N}^{\circ}$ adopters } & $0.00894 * * *$ & $0.00303^{* * *}$ & $0.00506 * * *$ & -0.000242 & $0.00219^{* * *}$ & $-0.00646 * * *$ \\
\hline & $(0.000444)$ & $(0.000222)$ & $(0.000973)$ & $(0.000457)$ & $(0.000476)$ & $(0.000542)$ \\
\hline & \multicolumn{6}{|c|}{ Environmental and location variables } \\
\hline \multirow{2}{*}{ Rainfall } & $-0.000196 * *$ & $7.54 \mathrm{e}-05^{* *}$ & $-0.000190 * * *$ & $-0.000184 * * *$ & - & $-0.000127 * * *$ \\
\hline & $(7.98 \mathrm{e}-05)$ & $(2.97 e-05)$ & $(5.52 e-05)$ & $(5.20 \mathrm{e}-05)$ & $\begin{array}{c}0.000163 * * * \\
(4.80 \mathrm{e}-05)\end{array}$ & $(3,94 \mathrm{e}-05)$ \\
\hline \multirow{2}{*}{ Soil quality } & $0.455^{* * *}$ & $-0.845^{* * *}$ & $0.322 * * *$ & 0.0874 & $0.217 * *$ & -0.0240 \\
\hline & $(0.141)$ & $(0.0500)$ & $(0.112)$ & $(0.0811)$ & $(0.0867)$ & $(0.0693)$ \\
\hline \multirow[t]{2}{*}{ North zone } & $-4.810 * * *$ & $1.058 * * *$ & $-5.500 * * *$ & -0.0539 & $-3.820 * * *$ & $0.609 * * *$ \\
\hline & $(0.159)$ & $(0.0991)$ & $(0.157)$ & $(0.163)$ & $(0.0962)$ & $(0.115)$ \\
\hline \multirow[t]{2}{*}{ Central zone } & $-0.163 * *$ & $0.491^{* * *}$ & 0.0163 & $0.199 * * *$ & 0.0380 & $0.217 * * *$ \\
\hline & $(0.0766)$ & $(0.0266)$ & $(0.0695)$ & $(0.0432)$ & $(0.0474)$ & $(0.0391)$ \\
\hline \multirow[t]{2}{*}{ Constant } & $-2.845^{* * *}$ & $-1.418 * * *$ & $-2.197 * * *$ & $-1.969 * * *$ & $-2.270 * * *$ & $-2.170^{* * *}$ \\
\hline & $(0.141)$ & $(0.0529)$ & $(0.165)$ & $(0.0914)$ & $(0.0909)$ & $(0.0791)$ \\
\hline \multirow[t]{2}{*}{ Athrho } & \multicolumn{2}{|c|}{$0.268 * *$} & \multicolumn{2}{|c|}{$2.193^{* * *}$} & \multicolumn{2}{|c|}{$2.405^{* * *}$} \\
\hline & \multicolumn{2}{|c|}{$(0.110)$} & & \\
\hline Obs. & \multicolumn{2}{|c|}{39,874} & \multicolumn{2}{|c|}{39,874} & \multicolumn{2}{|c|}{$\begin{array}{l}(0.220) \\
39,874\end{array}$} \\
\hline
\end{tabular}

Note: Robust standard errors in parentheses. ${ }^{* * *} \mathrm{p}<0.01,{ }^{* *} \mathrm{p}<0.05,{ }^{*} \mathrm{p}<0.1$. 
Table 4. Estimates of the Bivariate Probit Model for Insurance Adoption (Non-family Farmers)

\begin{tabular}{|c|c|c|c|c|c|c|}
\hline Variables & $\begin{array}{c}\text { Insurance } \\
\text { (1) }\end{array}$ & $\begin{array}{c}\text { Certified } \\
\text { seed } \\
(2) \\
\end{array}$ & $\begin{array}{c}\text { Insurance } \\
\text { (3) }\end{array}$ & $\begin{array}{c}\text { Biological } \\
\text { control } \\
(4)\end{array}$ & $\begin{array}{c}\text { Insurance } \\
\text { (5) }\end{array}$ & $\begin{array}{l}\text { Modern } \\
\text { irrigation } \\
(6)\end{array}$ \\
\hline & \multicolumn{6}{|c|}{ Technology } \\
\hline \multirow[t]{2}{*}{ Certified seed } & -0.289 & & $0.183 *$ & & $0.163 *$ & \\
\hline & $(0.326)$ & & $(0.0959)$ & & $(0.0910)$ & \\
\hline \multirow{2}{*}{$\begin{array}{l}\text { Biological } \\
\text { control }\end{array}$} & $0.286 * * *$ & & 0.658 & & $0.261^{* * *}$ & \\
\hline & $(0.0943)$ & & $(0.841)$ & & $(0.0977)$ & \\
\hline \multirow{3}{*}{$\begin{array}{l}\text { Modern } \\
\text { irrigation }\end{array}$} & $0.184^{* *}$ & & $0.184^{*}$ & & -0.785 & \\
\hline & $(0.0923)$ & & $(0.0937)$ & & $(0.579)$ & \\
\hline & \multicolumn{6}{|c|}{ Household and farm characteristics } \\
\hline \multirow{2}{*}{$\begin{array}{l}\text { Gender } \\
(\text { Male=1) }\end{array}$} & -0.0452 & 0.0103 & -0.0344 & $-0.195 * *$ & -0.105 & $-0.210 * * *$ \\
\hline & $(0.0849)$ & $(0.0683)$ & $(0.0921)$ & $(0.0809)$ & $(0.0867)$ & $(0.0754)$ \\
\hline \multirow[t]{2}{*}{ Age } & -0.00330 & -0.00172 & -0.00309 & -0.000386 & -0.00322 & -0.00180 \\
\hline & $(0.00271)$ & $(0.00197)$ & $(0.00272)$ & $(0.00258)$ & $(0.00259)$ & $(0.00224)$ \\
\hline \multirow[t]{2}{*}{ Reside on farm } & -0.0449 & -0.0538 & -0.0435 & 0.0554 & -0.00980 & 0.0918 \\
\hline & $(0.0736)$ & $(0.0581)$ & $(0.0743)$ & $(0.0718)$ & $(0.0729)$ & $(0.0680)$ \\
\hline \multirow[t]{2}{*}{ Education } & $0.0342 * *$ & $0.0204^{*}$ & $0.0286^{*}$ & $0.0449 * * *$ & $0.0517 * * *$ & $0.0755 * * *$ \\
\hline & $(0.0153)$ & (0.0118) & $(0.0170)$ & $(0.0140)$ & (0.0195) & $(0.0133)$ \\
\hline \multirow[t]{2}{*}{ Dependence } & $0.0605^{*}$ & 0.0108 & $0.0623^{*}$ & -0.0359 & $0.0708 * *$ & $0.0593 * *$ \\
\hline & (0.0332) & $(0.0239)$ & $(0.0336)$ & $(0.0310)$ & (0.0318) & $(0.0287)$ \\
\hline \multirow[t]{2}{*}{ Capital } & $0.0564 * * *$ & $0.116^{* * *}$ & $0.0378 *$ & $0.0662 * * *$ & $0.0650 * * *$ & $0.0761^{* * *}$ \\
\hline & $(0.0144)$ & $(0.0139)$ & (0.0202) & $(0.0120)$ & (0.0166) & $(0.0114)$ \\
\hline \multirow[t]{2}{*}{ Land } & $0.000123^{*}$ & $2.50 \mathrm{e}-05$ & $0.000125 *$ & $-7.29 e-05$ & $0.000128 * *$ & $5.70 \mathrm{e}-05$ \\
\hline & (6.93e-05) & $(8.16 e-05)$ & (7.26e-05) & $(0.000100)$ & (6.49e-05) & $(8.60 \mathrm{e}-05)$ \\
\hline \multirow[t]{2}{*}{ Yield } & $0.00789 * * *$ & & $0.00786 * * *$ & & $0.00718 * * *$ & \\
\hline & (0.00192) & & (0.00195) & & $(0.00201)$ & \\
\hline
\end{tabular}




\begin{tabular}{|c|c|c|c|c|c|c|}
\hline \multirow{3}{*}{ Secure tenure } & \multicolumn{6}{|c|}{ Institutional variables } \\
\hline & $0.366^{*}$ & $0.250^{*}$ & $0.350 *$ & -0.129 & $0.394^{* *}$ & 0.312 \\
\hline & $(0.200)$ & $(0.132)$ & $(0.207)$ & $(0.171)$ & $(0.198)$ & $(0.196)$ \\
\hline \multirow[t]{2}{*}{ Extension } & $0.374 * * *$ & $0.294 * * *$ & $0.336 * * *$ & 0.0959 & $0.367 * * *$ & $0.179 *$ \\
\hline & $(0.1000)$ & $(0.0775)$ & $(0.102)$ & $(0.0984)$ & $(0.0935)$ & $(0.0936)$ \\
\hline \multirow[t]{2}{*}{ Credit } & $0.649 * * *$ & $0.530 * * *$ & $0.564 * * *$ & $0.336 * * *$ & $0.602 * * *$ & $0.235 * * *$ \\
\hline & $(0.0812)$ & $(0.0606)$ & $(0.101)$ & $(0.0742)$ & $(0.0844)$ & $(0.0706)$ \\
\hline \multirow[t]{2}{*}{ Participation } & $0.282 * * *$ & $0.553 * * *$ & $0.183^{*}$ & $0.428 * * *$ & $0.248 * * *$ & $0.162 * *$ \\
\hline & $(0.0842)$ & $(0.0568)$ & (0.106) & $(0.0704)$ & $(0.0725)$ & $(0.0659)$ \\
\hline \multirow[t]{3}{*}{$\mathrm{N}^{\circ}$ adopters } & $0.00519 * * *$ & $0.00380 * * *$ & $0.00490 * * *$ & $-0.00192 * *$ & $0.00462 * * *$ & 0.000651 \\
\hline & (0.000849) & $(0.000749)$ & $(0.000828)$ & (0.000918) & $(0.000891)$ & (0.000948) \\
\hline & \multicolumn{6}{|c|}{ Environmental and location variables } \\
\hline \multirow[t]{2}{*}{ Rainfall } & $-0.000380 * * *$ & $-4.52 \mathrm{e}-05$ & $-0.000428^{* * *}$ & $0.000522 * * *$ & $-0.000482 * * *$ & $-0.000431 * * *$ \\
\hline & $(0.000138)$ & $(0.000102)$ & $(0.000161)$ & $(0.000125)$ & $(0.000136)$ & $(0.000125)$ \\
\hline \multirow[t]{2}{*}{ Soil quality } & $-0.623^{* *}$ & $-0.884 * * *$ & $-0.526^{* *}$ & 0.186 & -0.297 & $0.522 * * *$ \\
\hline & $(0.250)$ & $(0.150)$ & $(0.245)$ & $(0.198)$ & $(0.326)$ & $(0.187)$ \\
\hline \multirow[t]{2}{*}{ North zone } & -0.0381 & $0.676 * * *$ & -0.134 & -0.0498 & -0.149 & -0.138 \\
\hline & $(0.405)$ & $(0.218)$ & $(0.404)$ & $(0.338)$ & $(0.369)$ & $(0.244)$ \\
\hline \multirow[t]{2}{*}{ Central zone } & -0.0538 & $0.588 * * *$ & -0.146 & $0.247 * *$ & $-0.245 *$ & $-0.442 * * *$ \\
\hline & $(0.121)$ & $(0.0829)$ & $(0.117)$ & $(0.108)$ & $(0.135)$ & $(0.107)$ \\
\hline \multirow[t]{2}{*}{ Constant } & $-2.287 * * *$ & $-0.647 * * *$ & $-2.460 * * *$ & $-2.087 * * *$ & $-2.319 * * *$ & $-1.647 * * *$ \\
\hline & $(0.376)$ & $(0.230)$ & $(0.356)$ & $(0.299)$ & $(0.401)$ & $(0.294)$ \\
\hline \multirow[t]{2}{*}{ Athrho } & \multirow{2}{*}{\multicolumn{2}{|c|}{$\begin{array}{c}0.272 \\
(0187)\end{array}$}} & \multirow{2}{*}{\multicolumn{2}{|c|}{$\begin{array}{l}-0.204 \\
(0.469)\end{array}$}} & \multirow{2}{*}{\multicolumn{2}{|c|}{$\begin{array}{c}0.655 \\
(0.532)\end{array}$}} \\
\hline & & & & & & \\
\hline Obs. & \multicolumn{2}{|c|}{$\begin{array}{c}(0.10 /) \\
2,642\end{array}$} & \multicolumn{2}{|c|}{2,642} & \multicolumn{2}{|c|}{2,642} \\
\hline
\end{tabular}

Note: Robust standard errors in parentheses. ${ }^{* * *} \mathrm{p}<0.01,{ }^{* *} \mathrm{p}<0.05,{ }^{*} \mathrm{p}<0.1$. 


\section{Appendix A. Additional Tables and Figures}

Table A1. Estimates of the Bivariate Probit Model for Insurance Adoption

(Family Farmers and Central Zone)

\begin{tabular}{|c|c|c|c|c|c|c|}
\hline Variables & Insurance (1) & $\begin{array}{l}\text { Certified seed } \\
\text { (2) }\end{array}$ & $\begin{array}{c}\text { Insurance } \\
\text { (3) }\end{array}$ & $\begin{array}{c}\text { Biological } \\
\text { control } \\
(4)\end{array}$ & $\begin{array}{l}\text { Insurance } \\
\text { (5) }\end{array}$ & $\begin{array}{c}\text { Modern irrigation } \\
\text { (6) }\end{array}$ \\
\hline & \multicolumn{6}{|c|}{ Technology } \\
\hline \multirow[t]{2}{*}{ Certified seed } & -0.328 & & $0.201^{* * *}$ & & $0.294 * * *$ & \\
\hline & $(0.368)$ & & $(0.0479)$ & & $(0.0733)$ & \\
\hline \multirow[t]{2}{*}{ Biological control } & -0.0944 & & $-1.580 * * *$ & & -0.0652 & \\
\hline & $(0.143)$ & & $(0.0899)$ & & $(0.104)$ & \\
\hline \multirow[t]{3}{*}{ Modern irrigation } & 0.0106 & & -0.0435 & & $-1.685^{* * *}$ & \\
\hline & $(0.179)$ & & $(0.0943)$ & & $(0.157)$ & \\
\hline & \multicolumn{6}{|c|}{ Household and farm characteristics } \\
\hline \multirow[t]{2}{*}{ Gender (Male=1) } & -0.110 & 0.0166 & -0.0652 & -0.0401 & -0.0744 & 0.00206 \\
\hline & $(0.0866)$ & $(0.0455)$ & $(0.0624)$ & $(0.0666)$ & $(0.0740)$ & $(0.0707)$ \\
\hline \multirow[t]{2}{*}{ Age } & $-0.00617^{* *}$ & 0.000637 & -0.00272 & -0.000559 & $-0.00921^{* * *}$ & $-0.00862 * * *$ \\
\hline & $(0.00286)$ & $(0.00146)$ & $(0.00198)$ & $(0.00210)$ & $(0.00233)$ & $(0.00215)$ \\
\hline \multirow[t]{2}{*}{ Reside on farm } & $-0.245^{* * *}$ & $-0.199 * * *$ & $-0.106 *$ & 0.00234 & -0.0195 & $0.314 * * *$ \\
\hline & $(0.0763)$ & $(0.0429)$ & $(0.0580)$ & $(0.0675)$ & $(0.0724)$ & $(0.0755)$ \\
\hline \multirow[t]{2}{*}{ Education } & -0.0251 & $0.0575 * * *$ & -0.0150 & -0.00351 & -0.00329 & $0.0588 * * *$ \\
\hline & $(0.0260)$ & $(0.0118)$ & $(0.0171)$ & $(0.0184)$ & $(0.0220)$ & $(0.0175)$ \\
\hline \multirow[t]{2}{*}{ Dependence } & $0.174 * * *$ & $0.119 * * *$ & $0.108 * * *$ & $0.0662 * *$ & $0.137 * * *$ & $0.0797 * * *$ \\
\hline & $(0.0318)$ & $(0.0170)$ & $(0.0233)$ & $(0.0260)$ & $(0.0283)$ & $(0.0265)$ \\
\hline \multirow[t]{2}{*}{ Capital } & $0.312 * * *$ & $0.508 * * *$ & $0.303^{* * *}$ & $0.281^{* * *}$ & $0.202 * * *$ & $0.110 * *$ \\
\hline & $(0.0580)$ & $(0.0436)$ & $(0.0381)$ & $(0.0451)$ & $(0.0451)$ & $(0.0554)$ \\
\hline \multirow[t]{2}{*}{ Land } & $-0.00381^{*}$ & $-0.00205^{* *}$ & $-0.00488 * * *$ & $-0.00576 * * *$ & -0.000250 & 0.000635 \\
\hline & (0.00208) & $(0.000902)$ & (0.00129) & $(0.00142)$ & $(0.00151)$ & $(0.00114)$ \\
\hline \multirow[t]{2}{*}{ Yield } & $1.62 \mathrm{e}-05$ & & -0.00174 & & -0.00108 & \\
\hline & $(0.00213)$ & & $(0.00122)$ & & $(0.00161)$ & \\
\hline
\end{tabular}




\begin{tabular}{|c|c|c|c|c|c|c|}
\hline \multirow{3}{*}{ Secure tenure } & \multicolumn{6}{|c|}{ Institutional variables } \\
\hline & -0.0308 & 0.108 & -0.0226 & -0.0529 & 0.0464 & 0.144 \\
\hline & $(0.146)$ & $(0.0785)$ & $(0.113)$ & $(0.117)$ & $(0.122)$ & $(0.111)$ \\
\hline \multirow[t]{2}{*}{ Extension } & $0.368 * * *$ & $0.299 * * *$ & $0.316 * * *$ & $0.160 * *$ & $0.546 * * *$ & $0.661 * * *$ \\
\hline & $(0.0807)$ & $(0.0469)$ & $(0.0604)$ & $(0.0679)$ & $(0.0707)$ & $(0.0639)$ \\
\hline \multirow[t]{2}{*}{ Credit } & $0.839 * * *$ & $0.375^{* * *}$ & $0.639 * * *$ & $0.393^{* * *}$ & $0.624 * * *$ & 0.0920 \\
\hline & $(0.0825)$ & $(0.0604)$ & $(0.0682)$ & $(0.0843)$ & $(0.0786)$ & $(0.0963)$ \\
\hline \multirow[t]{2}{*}{ Participation } & $0.279 * * *$ & $0.516^{* * *}$ & $0.346 * * *$ & $0.396 * * *$ & 0.0925 & 0.00919 \\
\hline & $(0.0948)$ & $(0.0482)$ & $(0.0603)$ & $(0.0707)$ & $(0.0733)$ & $(0.0770)$ \\
\hline \multirow[t]{3}{*}{$\mathrm{N}^{\circ}$ adopters } & $0.00830^{* * *}$ & $0.00547^{* * *}$ & $0.00429 * * *$ & 0.000343 & $0.00323^{* * *}$ & $-0.00504 * * *$ \\
\hline & (0.000809) & $(0.000401)$ & $(0.000573)$ & $(0.000571)$ & $(0.000878)$ & $(0.000936)$ \\
\hline & \multicolumn{6}{|c|}{ Environmental and location variables } \\
\hline \multirow{2}{*}{ Rainfall } & $-0.00148 * * *$ & $-0.00346 * * *$ & $-0.00178 * * *$ & $-0.00216 * * *$ & -0.000232 & 0.000151 \\
\hline & $(0.000475)$ & (0.000195) & $(0.000251)$ & (0.000248) & $(0.000308)$ & $(0.000280)$ \\
\hline \multirow[t]{2}{*}{ Soil quality } & 0.130 & $-1.724 * * *$ & 0.210 & 0.0718 & $0.812 * * *$ & $0.808^{* * *}$ \\
\hline & $(0.305)$ & $(0.111)$ & $(0.165)$ & $(0.172)$ & (0.199) & $(0.160)$ \\
\hline \multirow[t]{2}{*}{ Constant } & $-1.351 * *$ & $1.475^{* * *}$ & $-0.00178^{* * *}$ & $-0.00216^{* * *}$ & -0.000232 & 0.000151 \\
\hline & $(0.530)$ & (0.181) & $(0.000251)$ & $(0.000248)$ & $(0.000308)$ & $(0.000280)$ \\
\hline \multirow[t]{2}{*}{ athrho } & \multicolumn{2}{|c|}{$0.484 *$} & \multicolumn{2}{|c|}{12.01} & \multicolumn{2}{|c|}{$1.795^{* * *}$} \\
\hline & \multicolumn{2}{|c|}{$(0.258)$} & \multicolumn{2}{|c|}{ (209.3) } & \multicolumn{2}{|c|}{$(0.350)$} \\
\hline Obs. & \multicolumn{2}{|c|}{5,659} & \multicolumn{2}{|c|}{5,659} & \multicolumn{2}{|c|}{5,659} \\
\hline
\end{tabular}

Note: Robust standard errors in parentheses. ${ }^{* * *} \mathrm{p}<0.01,{ }^{* *} \mathrm{p}<0.05$, ${ }^{*} \mathrm{p}<0.1$. 
Table A2. Estimates of the Bivariate Probit Model for Insurance Adoption (Family Farmers and Irrigator Sample)

\begin{tabular}{|c|c|c|c|c|c|c|}
\hline Variables & Insurance (1) & $\begin{array}{l}\text { Certified seed } \\
\text { (2) }\end{array}$ & $\begin{array}{l}\text { Insurance } \\
\text { (3) }\end{array}$ & $\begin{array}{c}\text { Biological control } \\
\text { (4) }\end{array}$ & $\begin{array}{c}\text { Insurance } \\
\text { (5) }\end{array}$ & $\begin{array}{c}\text { Modern irrigation } \\
\text { (6) }\end{array}$ \\
\hline & \multicolumn{6}{|c|}{ Technology } \\
\hline \multirow[t]{2}{*}{ Certified seed } & 0.294 & \multicolumn{3}{|c|}{$0.493 * * *$} & $0.401^{* * *}$ & \\
\hline & $(0.345)$ & \multicolumn{3}{|c|}{$(0.0503)$} & $(0.0665)$ & \\
\hline \multirow[t]{2}{*}{ Biological control } & $0.140 * *$ & \multicolumn{3}{|c|}{0.0659} & $0.119 * *$ & \\
\hline & $(0.0706)$ & \multicolumn{3}{|c|}{$(0.644)$} & $(0.0598)$ & \\
\hline \multirow[t]{3}{*}{ Modern irrigation } & $0.123 *$ & \multicolumn{3}{|c|}{$0.124 *$} & $-1.129 * * *$ & \\
\hline & $(0.0646)$ & \multicolumn{3}{|c|}{$(0.0645)$} & $(0.286)$ & \\
\hline & \multicolumn{6}{|c|}{ Household and farm characteristics } \\
\hline \multirow[t]{2}{*}{ Gender (Male=1) } & -0.0323 & $0.0699 * * *$ & -0.0383 & -0.0555 & -0.0532 & $-0.0924 * * *$ \\
\hline & $(0.0534)$ & $(0.0270)$ & $(0.0533)$ & $(0.0410)$ & $(0.0478)$ & $(0.0339)$ \\
\hline \multirow[t]{2}{*}{ Age } & $-0.00406 * *$ & $-6.75 e-05$ & $-0.00404^{* *}$ & 0.00162 & $-0.00428 * * *$ & -0.00169 \\
\hline & $(0.00165)$ & $(0.000844)$ & $(0.00166)$ & $(0.00132)$ & $(0.00146)$ & $(0.00106)$ \\
\hline \multirow[t]{2}{*}{ Reside on farm } & $-0.177 * * *$ & $-0.194 * * *$ & $-0.163 * * *$ & -0.0432 & -0.0584 & $0.246 * * *$ \\
\hline & $(0.0548)$ & $(0.0277)$ & $(0.0501)$ & $(0.0426)$ & $(0.0617)$ & $(0.0391)$ \\
\hline \multirow[t]{2}{*}{ Education } & 0.0143 & $0.0633 * * *$ & 0.0106 & $0.0467 * * *$ & $0.0394 * * *$ & $0.0933 * * *$ \\
\hline & $(0.0134)$ & $(0.00655)$ & $(0.0127)$ & $(0.00895)$ & $(0.0134)$ & $(0.00784)$ \\
\hline \multirow[t]{2}{*}{ Dependence } & $0.118 * * *$ & $0.0914^{* * *}$ & $0.110^{* * *}$ & $-0.0816 * * *$ & $0.130 * * *$ & $0.112 * * *$ \\
\hline & $(0.0223)$ & $(0.00958)$ & $(0.0219)$ & (0.0153) & $(0.0175)$ & $(0.0122)$ \\
\hline \multirow[t]{2}{*}{ Capital } & $0.117 * * *$ & $0.202^{* * *}$ & $0.110^{* * *}$ & $0.125^{* * *}$ & $0.138 * * *$ & $0.128 * * *$ \\
\hline & $(0.0215)$ & $(0.0177)$ & $(0.0241)$ & $(0.0130)$ & $(0.0133)$ & $(0.0127)$ \\
\hline \multirow[t]{2}{*}{ Land } & -0.000279 & $8.19 \mathrm{e}-05$ & -0.000280 & $-0.000321 *$ & $-4.12 e-05$ & $0.000208 * *$ \\
\hline & $(0.000180)$ & (8.91e-05) & $(0.000183)$ & $(0.000168)$ & $(0.000149)$ & (9.36e-05) \\
\hline \multirow[t]{3}{*}{ Yield } & $0.000586 * *$ & & $0.000587 * *$ & & $0.000521 *$ & \\
\hline & $(0.000275)$ & & $(0.000274)$ & & $(0.000273)$ & \\
\hline & \multicolumn{6}{|c|}{ Institutional variables } \\
\hline \multirow[t]{2}{*}{ Secure tenure } & 0.0712 & $0.163^{* * *}$ & 0.0571 & -0.0204 & 0.0555 & 0.0152 \\
\hline & $(0.0887)$ & $(0.0391)$ & $(0.0858)$ & $(0.0646)$ & $(0.0739)$ & $(0.0458)$ \\
\hline \multirow[t]{2}{*}{ Extension } & $0.388 * * *$ & $0.229 * * *$ & $0.376^{* * *}$ & $0.175 * * *$ & $0.500 * * *$ & $0.484 * * *$ \\
\hline & $(0.0534)$ & $(0.0265)$ & $(0.0513)$ & $(0.0402)$ & $(0.0499)$ & $(0.0307)$ \\
\hline
\end{tabular}




\begin{tabular}{|c|c|c|c|c|c|c|}
\hline Credit & $\begin{array}{l}0.853^{* * *} \\
(0.0691)\end{array}$ & $\begin{array}{c}0.496 * * * \\
(0.0336)\end{array}$ & $\begin{array}{c}0.824 * * * \\
(0.0572)\end{array}$ & $\begin{array}{l}0.368 * * * \\
(0.0468)\end{array}$ & $\begin{array}{l}0.739 * * * \\
(0.0709)\end{array}$ & $\begin{array}{c}0.157 * * * \\
(0.0428)\end{array}$ \\
\hline Participation & $\begin{array}{c}0.194 * * * \\
(0.0643)\end{array}$ & $\begin{array}{c}0.429 * * * \\
(0.0248)\end{array}$ & $\begin{array}{c}0.171^{* * *} \\
(0.0615)\end{array}$ & $\begin{array}{c}0.410 * * * \\
(0.0365)\end{array}$ & $\begin{array}{c}0.0970 * * \\
(0.0481)\end{array}$ & $\begin{array}{c}-0.0895 * * * \\
(0.0327)\end{array}$ \\
\hline $\mathrm{N}^{\circ}$ adopters & $\begin{array}{l}0.00647^{* * *} \\
(0.000496)\end{array}$ & $\begin{array}{l}0.00190^{* * *} \\
(0.000261)\end{array}$ & $\begin{array}{c}0.00635^{* * *} \\
(0.000492)\end{array}$ & $\begin{array}{c}-0.00118^{* * *} \\
(0.000410)\end{array}$ & $\begin{array}{c}0.00230 \\
(0.00171)\end{array}$ & $\begin{array}{r}-0.0106^{* * *} \\
(0.000641)\end{array}$ \\
\hline Dainfoll & \multicolumn{5}{|c|}{ Environmental and location variables } & $-2.30 e-05$ \\
\hline & $(0.000105)$ & (4.69e-05) & (0.000103) & (7.49e-05) & $(9.29 e-05)$ & $(4.83 e-05)$ \\
\hline Soil quality & $\begin{array}{c}0.378 * * \\
(0.150)\end{array}$ & $\begin{array}{l}-0.490 * * * \\
(0.0666)\end{array}$ & $\begin{array}{c}0.422^{* * *} \\
(0.151)\end{array}$ & $\begin{array}{c}0.565^{* * *} \\
(0.109)\end{array}$ & $\begin{array}{c}0.559 * * * \\
(0.124)\end{array}$ & $\begin{array}{c}0.585^{* * *} \\
(0.0781)\end{array}$ \\
\hline North zone & $\begin{array}{c}-0.815^{* *} \\
(0.363)\end{array}$ & $\begin{array}{c}0.462 * * * \\
(0.107)\end{array}$ & $\begin{array}{c}-0.852 * * \\
(0.357)\end{array}$ & $\begin{array}{l}-0.319^{*} \\
(0.170)\end{array}$ & $\begin{array}{c}-0.692^{* *} \\
(0.299)\end{array}$ & $\begin{array}{c}-0.308^{* * *} \\
(0.116)\end{array}$ \\
\hline Central zone & $\begin{array}{l}-0.189 * * \\
(0.0738)\end{array}$ & $\begin{array}{c}0.249 * * * \\
(0.0320)\end{array}$ & $\begin{array}{c}-0.204^{* * *} \\
(0.0702)\end{array}$ & $\begin{array}{c}0.145^{* * *} \\
(0.0511)\end{array}$ & $\begin{array}{c}-0.294^{* * * *} \\
(0.0627)\end{array}$ & $\begin{array}{c}-0.403 * * * \\
(0.0418)\end{array}$ \\
\hline Constant & $\begin{array}{c}-2.583^{* * * *} \\
(0.199)\end{array}$ & $\begin{array}{c}-0.857 * * * \\
(0.0801)\end{array}$ & $\begin{array}{c}-2.635^{* * * *} \\
(0.172)\end{array}$ & $\begin{array}{c}-2.092 * * * \\
(0.131)\end{array}$ & $\begin{array}{c}-2.215^{* * * *} \\
(0.257)\end{array}$ & $\begin{array}{c}-1.447 * * * \\
(0.0984)\end{array}$ \\
\hline athrho & \multicolumn{2}{|c|}{$\begin{array}{c}0.120 \\
(0.206)\end{array}$} & \multicolumn{2}{|c|}{$\begin{array}{l}0.0394 \\
(0.336)\end{array}$} & \multicolumn{2}{|c|}{$\begin{array}{l}0.939 * * * \\
(0.345)\end{array}$} \\
\hline Obs. & \multicolumn{2}{|c|}{15,048} & \multicolumn{2}{|c|}{15,048} & \multicolumn{2}{|c|}{15,048} \\
\hline
\end{tabular}

Note: Robust standard errors in parentheses. ${ }^{* * *} \mathrm{p}<0.01,{ }^{* *} \mathrm{p}<0.05,{ }^{*} \mathrm{p}<0.1$. 
Table A3. Estimates of the Multivariate Probit Model for Insurance Adoption (Irrigator Sample, Family Farmers and Central Zone)

\begin{tabular}{|c|c|c|c|c|}
\hline Variables & Insurance (1) & Certified seed (2) & Biological control (3) & Modern irrigation (4) \\
\hline \multicolumn{5}{|c|}{ Technology } \\
\hline Certified seed & $\begin{array}{c}0.333^{* * * *} \\
(0.119)\end{array}$ & & & \\
\hline Biological control & $\begin{array}{l}-0.155 \\
(0.229)\end{array}$ & & & \\
\hline Modern irrigation & $\begin{array}{c}-0.501^{* *} \\
(0.238)\end{array}$ & & & \\
\hline \multicolumn{5}{|c|}{ Household and farm characteristics } \\
\hline Gender (Male=1) & $\begin{array}{c}-0.137 \\
(0.0917)\end{array}$ & $\begin{array}{c}-0.000716 \\
(0.0502)\end{array}$ & $\begin{array}{c}-0.0440 \\
(0.0760)\end{array}$ & $\begin{array}{c}0.0576 \\
(0.0869)\end{array}$ \\
\hline Age & $\begin{array}{c}-0.00741^{* *} \\
(0.00309)\end{array}$ & $\begin{array}{c}0.00103 \\
(0.00164)\end{array}$ & $\begin{array}{c}0.00199 \\
(0.00247)\end{array}$ & $\begin{array}{c}-0.00929 * * * \\
(0.00263)\end{array}$ \\
\hline Reside on farm & $\begin{array}{l}-0.197 * * \\
(0.0825)\end{array}$ & $\begin{array}{c}-0.249 * * * \\
(0.0475)\end{array}$ & $\begin{array}{l}-0.0294 \\
(0.0728)\end{array}$ & $\begin{array}{c}0.328 * * * \\
(0.0892)\end{array}$ \\
\hline Education & $\begin{array}{l}-0.0321 \\
(0.0267)\end{array}$ & $\begin{array}{c}0.0623 * * * \\
(0.0135)\end{array}$ & $\begin{array}{c}0.0146 \\
(0.0201)\end{array}$ & $\begin{array}{c}0.0708 * * * \\
(0.0206)\end{array}$ \\
\hline Dependence & $\begin{array}{l}0.161^{* * *} \\
(0.0336)\end{array}$ & $\begin{array}{c}0.0963 * * * \\
(0.0190)\end{array}$ & $\begin{array}{c}0.0234 \\
(0.0285)\end{array}$ & $\begin{array}{c}0.0230 \\
(0.0305)\end{array}$ \\
\hline Capital & $\begin{array}{l}0.228 * * * \\
(0.0543)\end{array}$ & $\begin{array}{c}0.444^{* * *} \\
(0.0430)\end{array}$ & $\begin{array}{c}0.280 * * * \\
(0.0466)\end{array}$ & $\begin{array}{c}0.0782 \\
(0.0670)\end{array}$ \\
\hline Land & $\begin{array}{l}-0.00317 \\
(0.00257)\end{array}$ & $\begin{array}{c}-0.00268 * * \\
(0.00127)\end{array}$ & $\begin{array}{c}-0.00896 * * * \\
(0.00207)\end{array}$ & $\begin{array}{c}0.00523 * * * \\
(0.00163)\end{array}$ \\
\hline Yield & $\begin{array}{l}-0.000852 \\
(0.00225)\end{array}$ & & & \\
\hline \multicolumn{5}{|c|}{ Institutional variables } \\
\hline Secure tenure & $\begin{array}{l}-0.0916 \\
(0.158)\end{array}$ & $\begin{array}{c}0.0979 \\
(0.0870)\end{array}$ & $\begin{array}{l}-0.0511 \\
(0.137)\end{array}$ & $\begin{array}{l}0.252^{*} \\
(0.141)\end{array}$ \\
\hline Extension & $\begin{array}{c}0.342 * * * \\
(0.0892)\end{array}$ & $\begin{array}{l}0.242 * * * \\
(0.0518)\end{array}$ & $\begin{array}{c}0.222 * * * \\
(0.0747)\end{array}$ & $\begin{array}{c}0.690 * * * \\
(0.0742)\end{array}$ \\
\hline Credit & $0.761^{* * *}$ & $0.360 * * *$ & $0.358 * * *$ & 0.0343 \\
\hline
\end{tabular}




\begin{tabular}{lcccc} 
& $(0.0865)$ & $(0.0607)$ & $(0.0856)$ & $(0.106)$ \\
Participation & $0.168^{*}$ & $0.467 * * *$ & $0.325^{* * *}$ & -0.0684 \\
& $(0.0922)$ & $(0.0512)$ & $(0.0728)$ & $(0.0859)$ \\
$\mathrm{N}^{\circ}$ adopters & $0.00619^{* * *}$ & $0.00404^{* * *}$ & $-0.00166^{* * *}$ & $-0.00820^{* * *}$ \\
& $(0.000850)$ & $(0.000434)$ & $(0.000597)$ & $(0.00119)$ \\
Rainfall & \multicolumn{2}{c}{ Environmental and location variables } & \\
& -0.000653 & $-0.00315^{* * *}$ & $-0.00193^{* * *}$ & $0.00238^{* * *}$ \\
Soil quality & $(0.000420)$ & $(0.000230)$ & $(0.000286)$ & $(0.000427)$ \\
& $0.776^{* * *}$ & $-1.267 * * *$ & $0.369^{*}$ & $2.547^{* * *}$ \\
Constant & $(0.293)$ & $(0.135)$ & $(0.193)$ & $(0.267)$ \\
& $-1.993^{* * *}$ & $1.392^{* * *}$ & $-0.646^{* *}$ & $-4.122^{* * *}$ \\
& $(0.420)$ & $(0.209)$ & $(0.306)$ & $(0.424)$ \\
& & & & \\
& Athrho12 & 0.0462 & Athrho23 & $0.224^{* * *}$ \\
& & $(0.0519)$ & & $(0.0419)$ \\
& Athrho13 & 0.0131 & Athrho24 & -0.0228 \\
Obs. & $(0.0950)$ & & $(0.0483)$ \\
& Athrho14 & $0.244^{* * *}$ & Athrho34 & -0.0671 \\
& & $(0.0929)$ & & $(0.0586)$ \\
\hline
\end{tabular}

Note: Robust standard errors in parentheses. ${ }^{* * *} \mathrm{p}<0.01,{ }^{* *} \mathrm{p}<0.05,{ }^{*} \mathrm{p}<0.1$. 


\section{Table A4. Estimates of the Bivariate Probit Model for Insurance and Irrigation Technology Adoption with Instrumental Variables (Family Farmers, Central Zone and Irrigator Sample)}

\begin{tabular}{|c|c|c|c|c|}
\hline Variables & Insurance (1) & Modern irrigation (2) & Insurance (3) & Modern irrigation (3) \\
\hline \multicolumn{5}{|c|}{ Technology } \\
\hline \multirow[t]{2}{*}{ Certified seed } & $-1.778 * * *$ & & $-1.794 * * *$ & \\
\hline & $(0.148)$ & & $(0.139)$ & \\
\hline \multirow[t]{2}{*}{ Biological control } & $0.239 * *$ & & $0.234^{* *}$ & \\
\hline & $(0.0951)$ & & $(0.0913)$ & \\
\hline \multirow[t]{2}{*}{ Modern irrigation } & -0.101 & & -0.0902 & \\
\hline & $(0.104)$ & & (0.104) & \\
\hline \multicolumn{5}{|c|}{ Household and farm characteristics } \\
\hline \multirow[t]{2}{*}{ Gender (Male=1) } & -0.0683 & 0.0332 & -0.0676 & 0.0342 \\
\hline & $(0.0810)$ & $(0.0842)$ & $(0.0807)$ & $(0.0842)$ \\
\hline \multirow[t]{2}{*}{ Age } & $-0.00905^{* * *}$ & $-0.00733 * * *$ & $-0.00892 * * *$ & $-0.00733^{* * *}$ \\
\hline & $(0.00242)$ & $(0.00254)$ & $(0.00242)$ & $(0.00254)$ \\
\hline \multirow[t]{2}{*}{ Reside on farm } & -0.0565 & $0.244 * * *$ & -0.0612 & $0.244 * * *$ \\
\hline & $(0.0699)$ & $(0.0840)$ & $(0.0690)$ & $(0.0841)$ \\
\hline \multirow[t]{2}{*}{ Education } & 0.00805 & $0.0630 * * *$ & 0.00810 & $0.0631 * * *$ \\
\hline & $(0.0234)$ & $(0.0220)$ & $(0.0232)$ & $(0.0219)$ \\
\hline \multirow[t]{2}{*}{ Dependence } & $0.132 * * *$ & $0.0704^{* *}$ & $0.131^{* * *}$ & $0.0719 * *$ \\
\hline & $(0.0283)$ & $(0.0319)$ & $(0.0281)$ & $(0.0320)$ \\
\hline \multirow[t]{2}{*}{ Capital } & $0.197 * * *$ & 0.0785 & $0.192 * * *$ & 0.0814 \\
\hline & $(0.0483)$ & $(0.0682)$ & $(0.0484)$ & $(0.0671)$ \\
\hline \multirow[t]{2}{*}{ Land } & 0.00129 & $0.00393 * *$ & 0.00103 & $0.00387 * *$ \\
\hline & (0.00187) & $(0.00157)$ & (0.00190) & $(0.00158)$ \\
\hline \multirow[t]{2}{*}{ Yield } & -0.00146 & -0.00141 & -0.00142 & -0.00143 \\
\hline & $(0.00179)$ & $(0.00187)$ & $(0.00178)$ & $(0.00187)$ \\
\hline \multirow[t]{2}{*}{ Well source } & & $0.855^{* * *}$ & 0.206 & $0.883^{* * *}$ \\
\hline & & $(0.0835)$ & $(0.182)$ & $(0.0912)$ \\
\hline & & Institutional variable & & \\
\hline \multirow[t]{2}{*}{ Secure tenure } & 0.0360 & 0.148 & 0.0378 & 0.148 \\
\hline & $(0.132)$ & $(0.128)$ & $(0.131)$ & $(0.127)$ \\
\hline \multirow[t]{2}{*}{ Extension } & $0.519 * * *$ & $0.597 * * *$ & $0.516 * * *$ & $0.595 * * *$ \\
\hline & $(0.0805)$ & $(0.0810)$ & $(0.0794)$ & $(0.0806)$ \\
\hline \multirow[t]{2}{*}{ Credit } & $0.579 * * *$ & 0.00585 & $0.580 * * *$ & 0.00688 \\
\hline & $(0.0808)$ & $(0.0994)$ & $(0.0795)$ & $(0.0993)$ \\
\hline \multirow[t]{2}{*}{ Participation } & 0.0488 & 0.0390 & 0.0555 & 0.0384 \\
\hline & $(0.0765)$ & $(0.0877)$ & $(0.0758)$ & $(0.0867)$ \\
\hline \multirow[t]{2}{*}{$\mathrm{N}^{\circ}$ adopters } & 0.00144 & $-0.00636^{* * *}$ & 0.00147 & $-0.00628 * * *$ \\
\hline & (0.000979) & (0.000996) & (0.000924) & $(0.00102)$ \\
\hline \multirow{2}{*}{ Rainfall } & Env & onmental and location & ables & \\
\hline & $0.000661^{*}$ & $0.00260^{* * *}$ & $0.000692 *$ & $0.00259 * * *$ \\
\hline & (0.000397) & $(0.000412)$ & (0.000389) & $(0.000413)$ \\
\hline \multirow[t]{2}{*}{ Soil quality } & $1.537 * * *$ & $2.462 * * *$ & $1.530 * * *$ & $2.453 * * *$ \\
\hline & $(0.233)$ & $(0.254)$ & $(0.231)$ & $(0.256)$ \\
\hline \multirow[t]{2}{*}{ Constant } & $-2.559 * * *$ & $-4.340 * * *$ & $-2.586 * * *$ & $-4.342 * * *$ \\
\hline & $(0.367)$ & $(0.416)$ & $(0.366)$ & $(0.416)$ \\
\hline \multirow[t]{2}{*}{ athrho } & & $505^{* * *}$ & & $2.517 * * *$ \\
\hline & & $0.871)$ & & $(0.781)$ \\
\hline Obs. & & 4,044 & & 4,044 \\
\hline
\end{tabular}

Note: Robust standard errors in parentheses. ${ }^{* * *} \mathrm{p}<0.01,{ }^{* *} \mathrm{p}<0.05,{ }^{*} \mathrm{p}<0.1$. 